\title{
Chemoprevention of Prostate Cancer by Natural Agents: Evidence from Molecular and Epidemiological Studies
}

\author{
KEFAH MOKBEL, UMAR WAZIR and KINAN MOKBEL
}

The London Breast Institute, Princess Grace Hospital, London, U.K.

\begin{abstract}
Background/Aim: Prostate cancer is one of the most common cancers in men which remains a global public health issue. Treatment of prostate cancer is becoming increasingly intensive and aggressive, with a corresponding increase in resistance, toxicity and side effects. This has revived an interest in nontoxic and cost-effective preventive strategies including dietary compounds due to the multiple effects they have been shown to have in various oncogenic signalling pathways, with relatively few significant adverse effects. Materials and Methods: To identify such dietary components and micronutrients and define their prostate cancer-specific actions, we systematically reviewed the current literature for the pertinent mechanisms of action and effects on the modulation of prostate carcinogenesis, along with relevant updates from epidemiological and clinical studies. Results: Evidence from various recent experimental, clinical and epidemiological studies indicates that select dietary micronutrients (i.e., lycopene, epigallocatechin gallate, sulforaphane, indole-3-carbinol, resveratrol, quercetin, curcumin \& piperine) and zinc play a key role in prostate cancer prevention and progression and therefore hold great promise for the future overall management of prostate cancer. Conclusion: A formulation that comprises these micronutrients using the optimal, safest form and dosing should be investigated in future prostate cancer chemoprevention studies and as part of standard prostate cancer therapy.
\end{abstract}

This article is freely accessible online.

Correspondence to: Kefah Mokbel, The London Breast Institute, Princess Grace Hospital, 45 Nottingham Place, London W1U, U.K. Tel: +44 02079082040, Fax: +44 02079082275, e-mail: kefahmokbel@hotmail.com

Key Words: Micronutrient, phytochemicals, diet, cruciferous vegetables, prostate cancer, chemoprevention, review.
Prostate cancer is the second cause of cancer death in men accounting for an estimated 1.28 million deaths in $2018(1,2)$. The incidence of prostate cancer has been increasing globally with 1.3 million new cases reported in $2018(3,4)$. Prostate cancer is still considered the most common life-threatening malignancy affecting the male population in most European countries. In the UK, prostate cancer is the most common cancer among men accounting for $13 \%$ of all cancer deaths in males. Furthermore, the incidence of prostate cancer in British men has increased by more than two-fifths (44\%) since the early 1990s (5).

Based on clinical stage, histological grade and serum levels of prostate-specific antigen (PSA), current treatment options for prostate cancer include surgery, radiotherapy and/or chemotherapy (6-9). Such interventions are most effective in early disease, especially if it is still localised to the prostate. Once the tumour has metastasised to other organs of the body, it becomes highly resistant to currently available treatment modalities $(10,11)$.

For prostate cancer patients with locally advanced or metastatic disease, androgen deprivation therapy is the standard of treatment as pathogenesis of prostate cancer is highly dependent on androgen receptor signalling $(12,13)$. However, the efficacy of androgen-blockade as a treatment of prostate cancer is limited (14). After initial response to androgen deprivation therapy, most patients eventually progress to a highly aggressive, treatment-resistant form of the disease known as "castration-resistant" prostate cancer. This form of the disease poses a formidable therapeutic challenge and usually needs multiple combinations of therapeutic strategies to overcome (15-17).

While there are several chemotherapeutic agents targeting androgen receptor-dependent pathways, there is a relative lack of therapeutic options targeting androgen receptor-independent pathways, which would be of utility in the treatment of clinically aggressive castration-resistant disease (18). Whilst major advances have been made in the treatment of prostate cancer, the treatment options for locally advanced or metastasised prostate cancer are still limited and prognosis remains poor. 


\section{Chemoprevention}

Further to the preceding discussion, prostate cancer is therefore an ideal candidate for chemopreventive interventions owing to its high incidence, clinical variability, molecular heterogeneity, typical long latency, identifiable pre-malignant lesions, early detection tools and availability of a specific biomarker (i.e., PSA) $(19,20)$.

One such class of agents considered for prostate chemoprevention are the 5- $\alpha$ reductase inhibitors, such as finasteride and dutasteride. Their efficacy as chemopreventive agents has been borne out in clinical trials, albeit with a significant adverse effect profile. The FDA has recommended against the approval for these drugs for the prevention of prostate cancer based on risk-benefit analyses. Specifically, while they showed significant effects in reducing prostate cancer risk, these drugs have been reported to increase the risk for high-grade disease $(21,22)$. In addition, physicians were not prescribing $5-\alpha$ reductase inhibitors as chemopreventive drugs for prostate cancer. Whereas the majority of primary care physicians and urologists did not know that finasteride could be used for prostate cancer chemoprevention or never prescribe it for prevention, there have been major concerns of inducing high-grade tumours (23). An ideal preventive approach should delay prostate carcinogenesis, inhibit development of premalignant lesions into malignant disease and reduce the risk of reoccurrence for those who underwent successful primary treatment effectively with non-toxic features.

The epidemiology of prostate cancer shows strong geographic variations and substantial differences in incidence and mortality worldwide. Migrant studies have shown that Asian populations have a relatively lower incidence rate of prostate cancer in comparison to black and white Americans (24). In addition to genetic factors (25), environmental, especially nutritional influences, have been cited as potential causes for some of this variability and therefore might play significant roles in prostate carcinogenesis $(3,26)$.

The reported increased risk in populations emigrating from low to high risk countries provides strong support for modifiable environmental, particularly dietary, factors. Studies from populations of similar genetics but with different dietary and lifestyle-related factors have determined that immigrants from Asian countries to the USA who adopted a "Western-style" diet rich in meat and processed foods and lacking certain micronutrients of their native Asian diet had dramatically higher incidence and mortality rates of prostate cancer compared to their countries of origin. Although the rates of prostate cancer incidence in Asian countries has been increasing in recent years partly due to life-style changes particularly adopting "Westernstyle" diet, it is still comparatively lower than Western countries (27-33). Asian populations with high consumption of specific micronutrients have lower prostate cancer incidences versus countries consuming a Westernised diet (34).
Although it has been proposed that the reported lower rates of prostate cancer incidence in Asians were partly due to the insufficient practice of PSA testing among those populations $(4,35)$, the role of diet unquestionably cannot be discounted in relation to risk of prostate cancer $(36,37)$. Numerous studies have indicated that a poor diet contributes to $10 \%$ to $75 \%$ of various cancer-related deaths and that eating a healthy diet rich in fruits and vegetables may lower risk of prostate cancer risk by $75 \%$ (38).

Multiple studies evaluating empirically derived dietary patterns have reported an increased risk of prostate cancer, especially aggressive prostate cancer, with 'Westernised' dietary habits (39-41). In the Physicians' Health Study (926 men diagnosed with nonmetastatic prostate cancer and 8,093 participants), a post-diagnostic western diet was significantly associated with a higher risk of prostate cancer-specific and allcause mortality, and hazard ratios (HRs) were 2.53 $\left(95 \% \mathrm{CI}=1.00-6.42 ; p_{\text {trend }}=0.02\right)$ and $1.67(95 \% \mathrm{CI}=1.16-2.42$; $p_{\text {trend }}=0.01$ ), respectively (42). A dietary pattern characterised by higher intake of vegetables, fruits, legumes, whole grains and fish has been associated with a significantly reduced all-cause mortality (HR=0.64; 95\% CI $\left.=0.44-0.93 ; p_{\text {trend }}=0.02\right)(42)$.

There is sufficient evidence that constituents of the Mediterranean diet are inversely associated with risk of overall cancer including the prostate. Coastal countries in Southern Europe have lower prostate cancer incidence and mortality rates compared to other European countries (43). Greek migrant men in Australia who retained their native traditional Mediterranean diet have a lower risk of prostate cancer than those born in Australia or other migrants who adopted 'Western' dietary habits (44). A meta-analysis of data from 18 prospective cohort studies involving a total of 2,190,627 subjects with a follow-up time ranged from 4 to 20 years has provided a pooled relative risk of overall cancer of 0.94 [RR=0.94; 95\%CI $=0.92-0.96 ; p<0.00001\left(I^{2}=6 \% ; p=0.38\right)$ ] for a 2-point increase in adherence to the Mediterranean diet (45). Analogously, a meta-analysis of observational studies including 1,784,404 subjects has reported that highest adherence to a Mediterranean diet was significantly associated with reduced overall cancer mortality $(\mathrm{RR}=0.87,95 \% \mathrm{CI}=0.81$ $0.93, I^{2}=84 \%$ ) and risk of prostate cancer ( $\mathrm{RR}=0.96$, $95 \% \mathrm{CI}=0.92-1.00, I^{2}=0 \%$ ) (46). A prospective study involving 47,867 men in the USA has concluded that greater adherence to the Mediterranean diet after prostate cancer diagnosis was associated with a $22 \%$ reduction in overall mortality $\left(\mathrm{HR}=0.78 ; 95 \% \mathrm{CI}=0.67-0.90 ; p_{\text {trend }}=0.0007\right)(47)$.

Deviating from previous findings of inverse associations with prostate cancer, a Northern European case-control study (1,482 patients and 1,108 population-based controls) has found little support for an association between the Mediterranean diet and total prostate cancer risk in this population (48). The residual confounding and recall bias as well as limitations inherent in the study design and the 
construction of the Mediterranean Diet Score (MDS) leading to misclassification of exposure could explain the borderline association reported.

The main characteristics of Mediterranean diet typically include high intake of cruciferous vegetables, fruits, legumes, cereals and moderate to high consumption of fish and olive oil (49). The individual constituents of the Mediterranean diet have been extensively investigated in relation to prostate cancer. A meta-analysis of data on cancer incidence from large-scale multi-centre prospective cohort studies in 22 centres in nine European countries has reported a significant inverse association for vegetables and fruit intake and various cancers and concluded that selected European countries may benefit the most from nutritional intervention by increasing vegetable and fruit intake to reduce overall cancer risks (50). The association between fruit and vegetables intake and the risk of fourteen different common cancers was evaluated in a network of Italian and Swiss case-control studies $(10,000$ cases with 1,294 prostate cancer cases and 17,000 controls) demonstrating a favourable role of high consumption of vegetables and fruits for the risk of various common cancers including the prostate. The inverse correlations reported were for both raw and cooked vegetables and cruciferous vegetables and the odds ratios for the highest compared with the lowest levels of consumption vegetables and fruits for prostate cancer risk was 0.9 (51). A relatively small case-control study (157 prostate cancer case and 158 controls) has shown a significant inverse correlation between prostate cancer risk and the consumption of vegetables and fruits $(p=0.029)$ (52). Furthermore, a statistically significant inverse association between the vegan diets and risk of prostate cancer was reported $(\mathrm{HR}=0.65 ; 95 \% \mathrm{CI}=0.49-0.85)$. When the analyses were stratified by race, this statistically significant protective association with a vegan diet remained for the whites $(\mathrm{HR}=0.63 ; 95 \% \mathrm{CI}=0.46-0.86) \quad$ (53). The North CarolinaLouisiana Prostate Cancer Project (855 African Americans and 945 European Americans) has reported that total antioxidant capacity from supplements and diet was correlated with significantly lower odds of high aggressive prostate cancer in all participants, $\mathrm{OR}=0.31 \quad[95 \% \mathrm{CI}=0.15-0.67 ; p$-trend $<0.01]$ and African Americans and European Americans, $\mathrm{OR}=0.28$ [95\% CI $=0.08-0.96 ; \quad p$-trend $<0.001] \quad$ and $\quad \mathrm{OR}=0.36$ $(95 \% \mathrm{CI}=0.15-0.86 ; p$-trend=0.58), respectively (54).

The findings strongly suggest that a diet rich in specific naturally available micronutrients and phytochemicals with antioxidant properties may prevent or delay development, progression and/or recurrence of prostate cancer $(26,55-57)$. Vitamins, minerals, carotenoids, flavonoids and polyphenols that are abundant at high levels in vegetables and fruits have been extensively studied to explore their chemopreventive properties for prostate cancer. A major factor in the efficacy of dietary agents lies in their natural and raw form. In addition to generating by-products and altering the structure and digestibility of food, cooking can cause considerable losses in essential micronutrients (58-62). Pooled analysis of casecontrol studies have reported that the inverse association between consumption of raw and cooked vegetables and prostate cancer risk was somewhat stronger for raw compared to cooked vegetables [OR for the highest vs. the lowest intakes were 0.87 and 0.74 , respectively] (51).

There is a limited number of micronutrients and phytochemicals that have been evaluated in clinical studies, with varying success yet mostly favourable results. There is increasing evidence from a myriad of laboratory, animal, epidemiologic studies and available clinical trials that specific dietary agents (namely Lycopene, Epigallocatechin gallate, Sulforaphane, Indole-3-Carbinol, Resveratrol, Quercetin, Curcumin \& Piperine) and Zinc display the ability to inhibit signalling pathways which lead to prostate carcinogenesis (3, 63). Prostate tumour mass has been shown to comprise a highly heterogeneous population of cancerous cells and carcinogenesis is considered a process with multiple stages through which cancer cells often activate alternative survival oncogenic signalling pathways leading to development of drug resistance and failure of targeted therapy $(20,64)$. These dietary agents with their multi-targeted 'pleiotropic' effects are expected to be exceedingly effective due to their ability to regulate the activation of alternative survival oncogenic signalling pathways, with favourable side effects and, therefore, could play a crucial role in prostate cancer prevention. Combinations containing such micronutrients have been shown to exert potentially synergistic protective effects against prostate cancer and thus produce a more robust inhibition of carcinogenesis than each component separately (65). Furthermore, findings from systematic reviews of randomised controlled trials and prospective cohort studies have shown that adding micronutrients to cancer patients' treatment increases patient adherence to therapy, enhances response to the treatment, reduces side effects and doselimiting toxicities, reduces disease recurrence and mortality and improves overall prognosis and quality of life (66-70). Hence, it is also prudent that prostate cancer patients, with or without concurrent treatment, to supplement their diets with certain immuno-stabilising and antioxidant micronutrients during treatment.

\section{Materials and Methods}

The methodology for this review involved electronic searches across NCBI's PubMed database, MEDLINE and the Cochrane Library up to July 2019 for epidemiological and clinical trial studies reporting prostate cancer-specific risks and recurrence in relation to intake of dietary agents. In vitro and animal studies investigating the effects of dietary components on prostate tumours and prostate cancer cells were included in the search. In order to stay within the scope of a concise review, we have restricted our search to the key search terms 'prostate cancer and vitamins', 'prostate cancer and minerals', 
'prostate cancer and nutrients', 'prostate cancer and nutrition', 'prostate cancer and diet', 'prostate cancer prevention' and 'prostate cancer and natural products'.

Abstracts were initially screened and agents that were consistently found to be associated with lower risk of prostate cancer development and/or recurrence, and those for which there was robust molecular evidence of activity against prostate cancer cells were selected. Reference list search yielded a total of 12,677 potentially relevant publications. Two reviewers independently further evaluated relevance and quality of the identified studies. References within the identified studies were consulted as well. After removing duplicates and using the most updated meta-analyses and systematic reviews when conflicting results were found and the latest publication when multiple articles for a single study existed, a total of 30 articles and reviews with sufficient quality that matched our initial search criteria remained for full-text evaluation.

Animal and in vitro studies with the most robust and highest levels of molecular evidence for a protective effect and epidemiological studies demonstrating statistically significant inverse associations were selected to identify the dietary agents to be covered in our review. Dietary factors associated with no evidence, weak or frequently inconsistent evidence for protective effects against prostate cancer were not included in this review. For each compound identified in the relevant studies, the hazard ratio (HR) or relative risk (RR) and 95\% confidence intervals (CI) are reported.

\section{Results}

We have identified 6 micronutrients i) Lycopene, ii) Epigallocatechin gallate, iii) Sulforaphane, iv) Indole-3Carbinol, v) Resveratrol and vi) Quercetin), 2 spices i) curcumin and ii) piperine and one mineral, namely Zinc, that correlated with lower risks of prostate cancer and/or recurrence. Results of this literature search for epidemiological studies demonstrating the chemopreventive effects of these micronutrients against prostate cancer are shown in Table I. The mechanisms of action by which these micronutrients exert their protective effects on prostate cancer are presented in Table II.

\section{Lycopene}

Lycopene is one of the main antioxidant carotenoids that gives tomatoes and tomato-derived products their colour. There is sufficient evidence that high intake of tomato, tomato products or lycopene supplementation can decrease the risk of prostate cancer. There have been no significant adverse effects attributed to lycopene supplementation when consumed for a long period $(71,72)$. The denoted protective effects of tomato and tomato products are largely conferred by high concentration of lycopene (73). While lycopene is the most effective scavenger of singlet oxygen among the main naturally occurring carotenoids $(74,75)$, its prostate cancer protective effects were difficult to explain by its potent antioxidant effects. The anticarcinogenic activities of Lycopene are considered to be exerted via other multiple mechanisms including protection of vital cellular biomolecules such as DNA and lipoproteins, intercellular gap junction communication, inhibition of proliferation of cancerous cells at the G0-G1 cell cycle phase and modulation of hormonal and immune systems (76-78). Lycopene has also been reported to inhibit prostate cancer cell proliferation via activation of the peroxisome proliferator-activated receptor gamma (PPAR $\gamma$ )liver $\mathrm{X}$ receptor alpha (LXR $\alpha$ )-ATP-binding cassette transporter 1 (ABCA1) pathway (PPAR $\gamma$-LXR $\alpha$-ABCA 1 pathway) and modulation of the expression of genes related to growth and apoptosis such as cyclin-dependent kinase 7 (CDK7), epidermal growth factor receptor (EGFR), insulinlike growth factor-1 receptor (IGF-1R) and BCL2 $(79,80)$.

A prospective cohort study of 47,365 participants for 12 years has revealed a statistically significant association between lycopene intake and prostate cancer risk; The reduction in prostate cancer risk was $17 \%$ (RR for high vs. low quintiles $\left.=0.83 ; 95 \% \mathrm{CI}=0.70-0.98 ; p_{\text {trend }}=0.02\right)$ and $22 \%$ when the deciles rather than quintiles were analysed (RR for high $v s$. low deciles $=0.78 ; 95 \% \mathrm{CI}=0.65-0.94)$ (81). A smaller yet more recent nested case-control study involving 1,806 prostate cancer cases and 12,005 controls has shown that adherence to intake of tomato products was inversely associated with $18 \%$ overall prostate cancer risk $(\mathrm{OR}=0.82$; $95 \% \mathrm{CI}=0.70-0.97 ; p=0.02)(82)$. In line with the previous studies, a more recent meta-analysis of 22 case-control (13,999 cases and 22,028 controls) and 5 cohort studies (8,619 cases and 187,417 participants) has reported a statistically significant inverse association between lycopene and raw or cooked tomatoes intake and prostate cancer $(\mathrm{OR}=0.94$, $95 \% \mathrm{CI}=0.89-1.00)$ and $(\mathrm{RR}=0.9, \quad 95 \% \mathrm{CI}=0.85-0.95)$, respectively (83).

Analogously, a recent and more inclusive meta-analysis of thirty studies $(24,222$ cases and 260,461 participants) has also demonstrated significant inverse associations between consumption of total tomato, tomato foods, and cooked tomatoes and sauces and prostate cancer risk $(\mathrm{RR}=0.81$, 95\% CI $=0.71-0.92, p=0.001),(\mathrm{RR}=0.84,95 \% \mathrm{CI}=0.72-0.98$, $p=0.030)$ and $(\mathrm{RR}=0.84,95 \% \mathrm{CI}=0.73-0.98, p=0.029)$, respectively. Nevertheless, there were no associations reported for raw tomatoes and prostate cancer risk $(\mathrm{RR}=0.96$, 95\% CI=0.84-1.09, $p=0.487)$. Whereas significant doseresponse associations were reported for total intake of tomato $(p=0.040)$, cooked tomatoes and sauces $(p<0.001)$ and raw tomatoes $(p=0.037)$, there was no significant association with tomato foods $\left(p_{\text {linear }}=0.511, p_{\text {nonlinear }}=0.289\right)$. When further stratified by study design, the pooled RR were 0.68 $\left(95 \% \mathrm{CI}=0.55-0.84, \quad p<0.001, \quad I^{2}=77.4 \%\right) \quad$ and 0.92 $\left(95 \% \mathrm{CI}=0.86-0.98, p=0.013, I^{2}=41.1 \%\right)$ for case-control and cohort studies, respectively. Interestingly, regarding tomato foods, the pooled RR for case-control studies was 0.69 (95\% CI $\left.=0.53-0.91, \quad p=0.008, \quad I^{2}=80.3 \%\right) \quad$ and 1.00 $\left(95 \% \mathrm{CI}=0.87-1.15, p=0.963, I^{2}=57 \%\right)$ for cohort and nested 
Table I. Summary of studies selected in our review reporting on risk estimates of the associations between intake of selected micronutrients (highest vs. lowest or frequent $v$ s. nonfrequent) and prostate cancer risk.

\begin{tabular}{|c|c|c|c|c|c|c|c|c|}
\hline $\begin{array}{l}\text { Dietary } \\
\text { pattern }\end{array}$ & $\begin{array}{l}\text { Study name/ } \\
\text { Reference }\end{array}$ & $\begin{array}{l}\text { Study } \\
\text { design }\end{array}$ & & Exposure & & $\begin{array}{r}\text { Risk } \\
\quad(95\end{array}$ & timate & Outcome \\
\hline Micronutrient & & & & & $\begin{array}{c}\text { RR, HR, } \\
\text { OR }(95 \% \mathrm{CI})\end{array}$ & $\begin{array}{c}p \\
\text { trend }\end{array}$ & $\begin{array}{l}\text { Hetero- } \\
\text { geneity } \\
\text { test } I^{2}(\%)\end{array}$ & \\
\hline
\end{tabular}

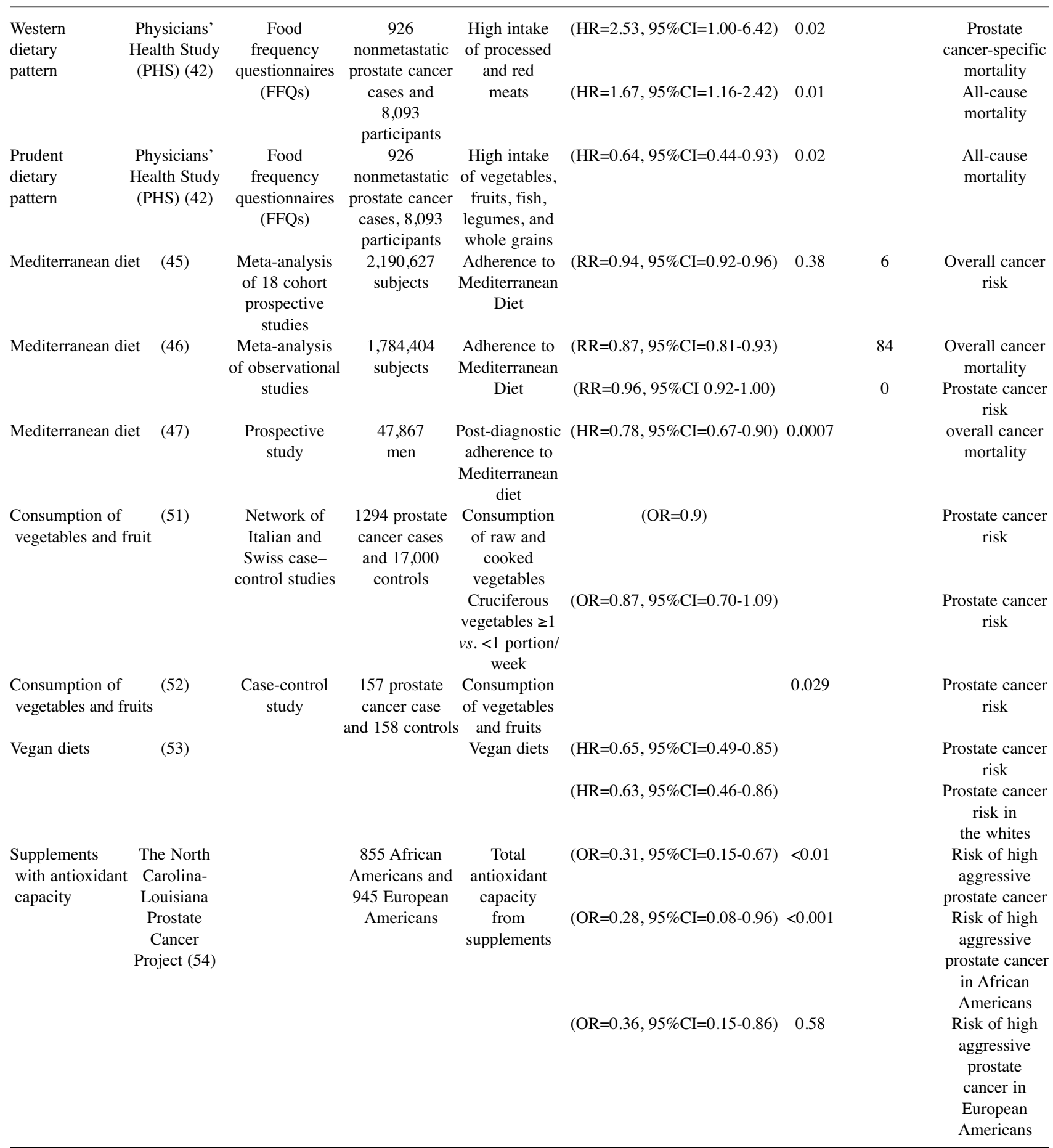


Table I. Continued

\begin{tabular}{lcccccc}
\hline $\begin{array}{l}\text { Dietary } \\
\text { pattern } \\
\text { or }\end{array}$ & $\begin{array}{c}\text { Study name/ } \\
\text { Reference }\end{array}$ & $\begin{array}{c}\text { Study } \\
\text { design }\end{array}$ & $\begin{array}{c}\text { Population } \\
\text { (case, } \\
\text { participants) }\end{array}$ & Exposure & & $\begin{array}{c}\text { Risk estimate } \\
(95 \% \mathrm{CI})\end{array}$ \\
& & & & RR, HR, & $\begin{array}{c}p \\
\text { Hetero- } \\
\text { geneity } \\
\text { trend }\end{array}$ \\
test $\mathrm{I}^{2}(\%)$
\end{tabular}

\begin{tabular}{|c|c|c|c|c|c|c|c|c|}
\hline \multirow[t]{13}{*}{ Lycopene } & $(81)$ & $\begin{array}{l}\text { Prospective } \\
\text { Study }\end{array}$ & $\begin{array}{c}47,365 \\
\text { participants }\end{array}$ & $\begin{array}{c}\text { High } v s . \\
\text { low quintiles } \\
\text { of lycopene } \\
\text { intake } \\
\text { High } v s . \text { low } \\
\text { deciles } \\
\text { of lycopene } \\
\text { intake }\end{array}$ & $(\mathrm{RR}=0.78,95 \% \mathrm{CI}=0.65-0.94)$ & 0.02 & & $\begin{array}{l}\text { Prostate cancer } \\
\text { risk }\end{array}$ \\
\hline & (82) & $\begin{array}{l}\text { Nested } \\
\text { case-control } \\
\text { study }\end{array}$ & $\begin{array}{l}1,806 \text { prostate } \\
\text { cancer cases } \\
\text { and } 12,005 \\
\text { controls }\end{array}$ & $\begin{array}{l}\text { Tomato } \\
\text { products } \\
\text { intake }\end{array}$ & $(\mathrm{OR}=0.82,95 \% \mathrm{CI}=0.70-0.97)$ & 0.02 & & $\begin{array}{c}\text { Prostate cancer } \\
\text { risk }\end{array}$ \\
\hline & (83) & $\begin{array}{l}\text { Meta-analysis } \\
\text { of } 22 \\
\text { case-control } \\
\text { and } 5 \text { cohort } \\
\text { studies }\end{array}$ & $\begin{array}{c}\text { Case-control } \\
\text { studies }(13,999 \\
\text { cases and } \\
22,028 \text { controls }) \\
\text { cohort studies } \\
(8,619 \text { cases } \\
\text { and } 187,417 \\
\text { participants })\end{array}$ & $\begin{array}{l}\text { Lycopene } \\
\text { intake } \\
\text { Raw or } \\
\text { cooked } \\
\text { tomatoes } \\
\text { intakes }\end{array}$ & $\begin{array}{l}(\mathrm{RR}=0.94,95 \% \mathrm{CI}=0.89-1.00) \\
(\mathrm{RR}=0.9,95 \% \mathrm{CI}=0.85-0.95)\end{array}$ & & & $\begin{array}{c}\text { Prostate cancer } \\
\text { risk } \\
\text { Prostate cancer } \\
\text { risk }\end{array}$ \\
\hline & (84) & $\begin{array}{l}\text { Meta-analysis } \\
\text { of } 30 \text { studies }\end{array}$ & $\begin{array}{l}24,222 \text { cases } \\
\text { and } 260,461 \\
\text { participants }\end{array}$ & $\begin{array}{c}\text { Total } \\
\text { intake } \\
\text { of tomato }\end{array}$ & $\begin{array}{l}(\mathrm{RR}=0.81,95 \% \mathrm{CI}=0.71-0.92) \\
(\mathrm{RR}=0.68,95 \% \mathrm{CI}=0.55-0.84)\end{array}$ & $\begin{array}{r}0.001 \\
<0.001\end{array}$ & 77.4 & $\begin{array}{c}\text { Prostate cancer } \\
\text { risk } \\
\text { Prostate cancer } \\
\text { risk for case- } \\
\text { control studies }\end{array}$ \\
\hline & & & & & $(\mathrm{RR}=0.92,95 \% \mathrm{CI}=0.86-0.98)$ & 0.013 & 41.1 & $\begin{array}{l}\text { Prostate cancer } \\
\text { risk for } \\
\text { cohort studies }\end{array}$ \\
\hline & & & & & $(\mathrm{RR}=0.89,95 \% \mathrm{CI}=0.77-1.03)$ & 0.113 & 35.3 & $\begin{array}{c}\text { Risk of } \\
\text { advanced } \\
\text { prostate cancer }\end{array}$ \\
\hline & & & & & $(\mathrm{RR}=1.10,95 \% \mathrm{CI}=0.84-1.44)$ & 0.493 & 0 & $\begin{array}{c}\text { Risk of } \\
\text { advanced } \\
\text { prostate cancer } \\
\text { for case- } \\
\text { control studies }\end{array}$ \\
\hline & & & & & $(\mathrm{RR}=0.81,95 \% \mathrm{CI}=0.68-0.97)$ & 0.019 & 16.3 & $\begin{array}{c}\text { Risk of } \\
\text { advanced } \\
\text { prostate cancer } \\
\text { for cohort } \\
\text { studies }\end{array}$ \\
\hline & & & & $\begin{array}{c}\text { Raw } \\
\text { tomatoes }\end{array}$ & $(\mathrm{RR}=0.96,95 \% \mathrm{CI}=0.84-1.09)$ & 0.487 & & $\begin{array}{c}\text { Prostate cancer } \\
\text { risk }\end{array}$ \\
\hline & & & & & $(\mathrm{RR}=0.95,95 \% \mathrm{CI}=0.76-1.19)$ & 0.729 & 55.9 & $\begin{array}{l}\text { Prostate cancer } \\
\text { risk for case- } \\
\text { control studies }\end{array}$ \\
\hline & & & & & $(\mathrm{RR}=0.96,95 \% \mathrm{CI}=0.81-1.14)$ & 0.557 & 60.6 & $\begin{array}{l}\text { Prostate cancer } \\
\text { risk for cohort } \\
\text { and nested case- } \\
\text { control studies }\end{array}$ \\
\hline & & & & $\begin{array}{l}\text { Tomato } \\
\text { foods }\end{array}$ & & 0.030 & & $\begin{array}{c}\text { Prostate cancer } \\
\text { risk }\end{array}$ \\
\hline & & & & & $(\mathrm{RR}=0.69,95 \% \mathrm{CI}=0.53-0.91)$ & 0.008 & 80.3 & $\begin{array}{l}\text { Prostate cancer } \\
\text { risk for case- } \\
\text { control studies }\end{array}$ \\
\hline
\end{tabular}


Table I. Continued

\begin{tabular}{|c|c|c|c|c|c|c|c|c|}
\hline \multirow{2}{*}{$\begin{array}{l}\text { Dietary } \\
\text { pattern } \\
\text { or } \\
\text { Micronutrient }\end{array}$} & \multirow[t]{2}{*}{$\begin{array}{l}\text { Study name/ } \\
\text { Reference }\end{array}$} & \multirow[t]{2}{*}{$\begin{array}{l}\text { Study } \\
\text { design }\end{array}$} & \multirow{2}{*}{$\begin{array}{l}\text { Population } \\
\quad \text { (case, } \\
\text { participants) }\end{array}$} & \multirow[t]{2}{*}{ Exposure } & & \multicolumn{2}{|c|}{$\begin{array}{l}\text { Risk estimate } \\
\quad(95 \% \mathrm{CI})\end{array}$} & \multirow[t]{2}{*}{ Outcome } \\
\hline & & & & & $\begin{array}{c}\text { RR, HR, } \\
\text { OR (95\%CI) }\end{array}$ & $\begin{array}{c}p \\
\text { trend }\end{array}$ & $\begin{array}{l}\text { Hetero- } \\
\text { geneity } \\
\text { test } I^{2}(\%)\end{array}$ & \\
\hline
\end{tabular}

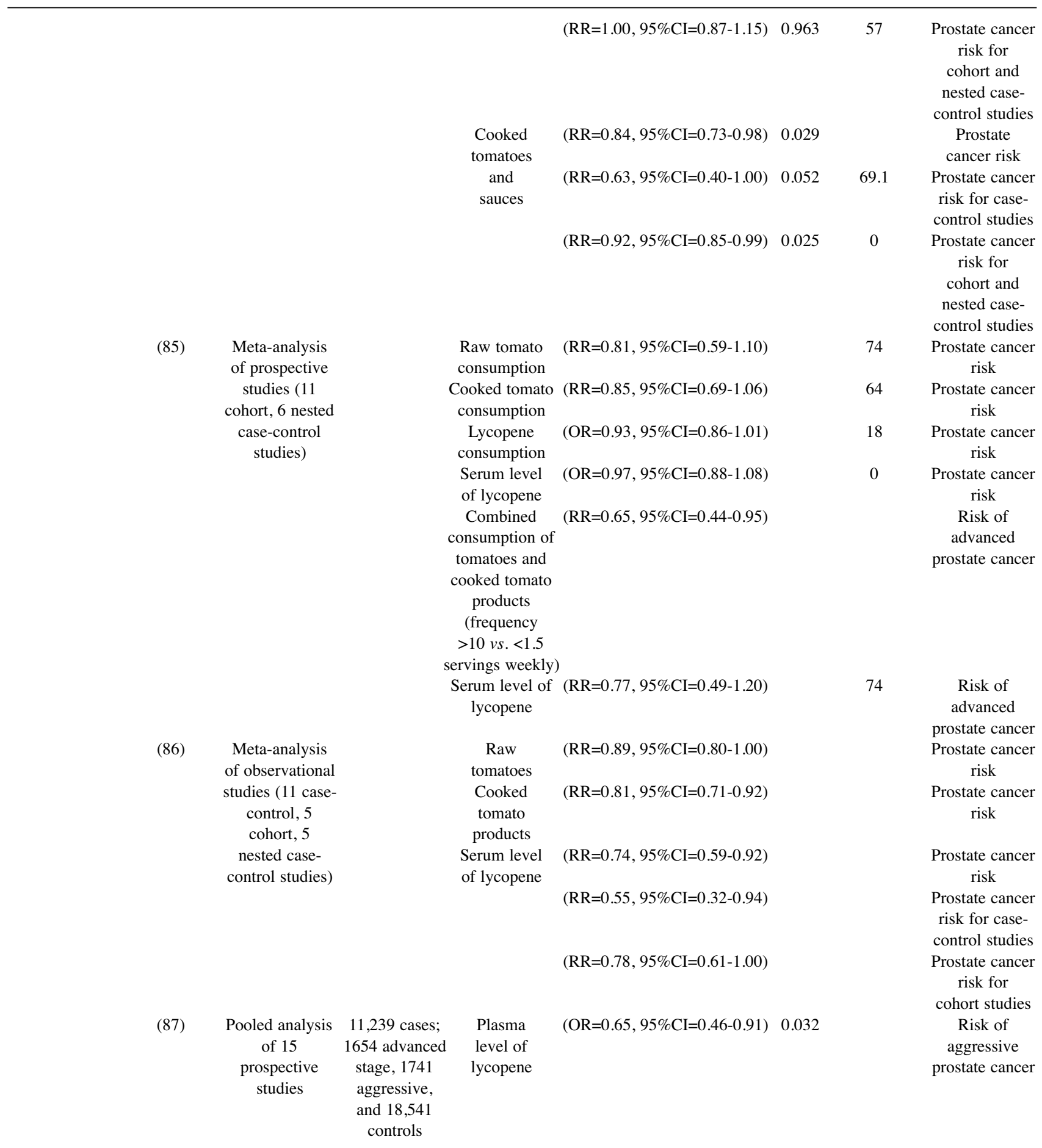


Table I. Continued

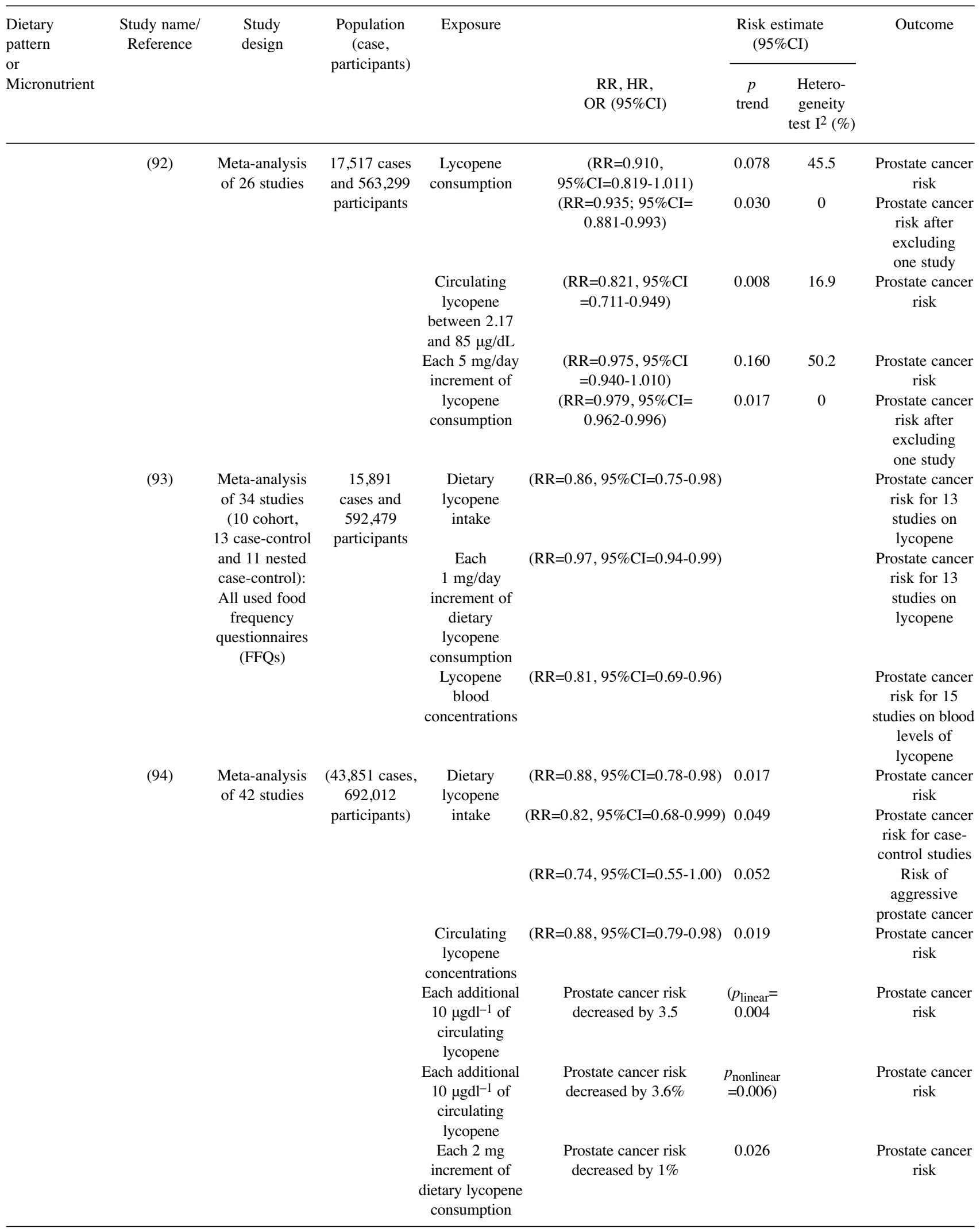


Table I. Continued

\begin{tabular}{|c|c|c|c|c|c|c|c|c|}
\hline \multirow{2}{*}{$\begin{array}{l}\text { Dietary } \\
\text { pattern } \\
\text { or } \\
\text { Micronutrient }\end{array}$} & \multirow[t]{2}{*}{$\begin{array}{l}\text { Study name/ } \\
\text { Reference }\end{array}$} & \multirow[t]{2}{*}{$\begin{array}{l}\text { Study } \\
\text { design }\end{array}$} & \multirow{2}{*}{$\begin{array}{l}\text { Population } \\
\quad \text { (case, } \\
\text { participants) }\end{array}$} & \multirow[t]{2}{*}{ Exposure } & & \multicolumn{2}{|c|}{$\begin{array}{l}\text { Risk estimate } \\
\quad(95 \% \mathrm{CI})\end{array}$} & \multirow[t]{2}{*}{ Outcome } \\
\hline & & & & & $\begin{array}{c}\mathrm{RR}, \mathrm{HR}, \\
\mathrm{OR}(95 \% \mathrm{CI})\end{array}$ & $\begin{array}{c}p \\
\text { trend }\end{array}$ & $\begin{array}{l}\text { Hetero- } \\
\text { geneity } \\
\text { test } I^{2}(\%)\end{array}$ & \\
\hline
\end{tabular}

Epigallocatechin-

3-gallate (EGCG)

$(101)$

Meta-analysis

of 13 observational

studies

$(102)$

Meta-analysis

of 21 studies

(103) Pooled analysis

of 21 studies

$\begin{array}{cc}\begin{array}{c}\text { Green tea } \\ \text { consumption }\end{array} & (\mathrm{OR}=0.62,95 \% \mathrm{CI}=0.38-1.01) \\ & (\mathrm{OR}=0.43,95 \% \mathrm{CI}=0.25-0.73)\end{array}$

Tea consumption $(\mathrm{OR}=0.77,95 \% \mathrm{CI}=0.55-0.98)<0.001$ (both green and black)

Tea consumption $(\mathrm{OR}=0.84,95 \% \mathrm{CI}=0.71-0.98)$ (both green and black)

$(\mathrm{OR}=0.40,95 \% \mathrm{CI}=0.25-0.66)$

$(\mathrm{OR}=0.48,95 \% \mathrm{CI}=0.24-0.97)$

$(\mathrm{OR}=0.66,95 \% \mathrm{CI}=0.46-0.93)$

(95)

Meta-analysis of 13 studies

3,020 patients

Green tea catechins

$(\mathrm{OR}=0.39,95 \% \mathrm{CI}=0.16-10.97) \quad 0.044$

Green tea catechins

Green tea consumption studies and three randomised controlled trials

(107)

$500 \mathrm{ml} /$ day
$(\mathrm{RR}=0.81,95 \% \mathrm{CI}=0.67-0.97)$

$(\mathrm{RR}=0.893,95 \% \mathrm{CI}=$

0.796-1.002, $p=0.054$ )

$(\mathrm{OR}=0.52,95 \% \mathrm{CI}=0.35-0.79)$

$(\mathrm{OR}=0.30,95 \% \mathrm{CI}=0.18-0.48)$

$(\mathrm{RR}=0.86,95 \% \mathrm{CI}=0.50-1.47)$

$(\mathrm{RR}=0.60,95 \% \mathrm{CI}=0.34-1.06) \quad 0.03$
Green tea

consumption

$>7$ cups/day

Each 1 cup

increase of

green tea

per day

Total tea

Case-control 253 patients, study

419 controls

consumption

of 100 -

Total tea

consumption of $500 \mathrm{ml} /$ day

Green tea

consumption

3-4 cups/day

Green tea

consumption

$\geq 5$ cups/day
Prostate cancer risk

Prostate cancer risk for casecontrol studies Prostate cancer risk for 18 casecontrol studies Prostate cancer risk

Prostate cancer risk in Chinese studies

Prostate cancer risk in Indian studies

Risk of lowgrade prostate cancer

Prostate cancer risk in highgrade

intraepithelial neoplasia patients

Prostate cancer risk

Prostate cancer risk for the case-control studies

Prostate cancer risk

Prostate cancer risk

Prostate cancer risk

Prostate cancer risk

Risk of advanced prostate cancer Risk of advanced prostate cancer 
Table I. Continued

\begin{tabular}{|c|c|c|c|c|c|c|c|c|}
\hline \multirow{2}{*}{$\begin{array}{l}\text { Dietary } \\
\text { pattern } \\
\text { or } \\
\text { Micronutrient }\end{array}$} & \multirow[t]{2}{*}{$\begin{array}{l}\text { Study name/ } \\
\text { Reference }\end{array}$} & \multirow[t]{2}{*}{$\begin{array}{l}\text { Study } \\
\text { design }\end{array}$} & \multirow{2}{*}{$\begin{array}{l}\text { Population } \\
\quad \text { (case, } \\
\text { participants) }\end{array}$} & \multirow[t]{2}{*}{ Exposure } & & \multicolumn{2}{|c|}{$\begin{array}{l}\text { Risk estimate } \\
\quad(95 \% \mathrm{CI})\end{array}$} & \multirow[t]{2}{*}{ Outcome } \\
\hline & & & & & $\begin{array}{c}\mathrm{RR}, \mathrm{HR}, \\
\mathrm{OR}(95 \% \mathrm{CI})\end{array}$ & $\begin{array}{c}p \\
\text { trend }\end{array}$ & $\begin{array}{l}\text { Hetero- } \\
\text { geneity } \\
\text { test } \mathrm{I}^{2}(\%)\end{array}$ & \\
\hline
\end{tabular}

\begin{tabular}{|c|c|c|c|c|c|c|c|}
\hline \multirow[t]{3}{*}{$\begin{array}{l}\text { Sulforaphane \& } \\
\text { indole-3-carbinol }\end{array}$} & (149) & $\begin{array}{l}\text { Meta-analysis } \\
\text { of } 13 \text { studies } \\
\text { (7 cohort, } 6 \\
\text { population-based } \\
\text { case-control } \\
\text { studies) }\end{array}$ & & $\begin{array}{l}\text { Consumption } \\
\text { of cruciferous } \\
\text { vegetables }\end{array}$ & $\begin{array}{l}(\mathrm{RR}=0.90,95 \% \mathrm{CI}=0.85-0.96) \\
(\mathrm{RR}=0.79,95 \% \mathrm{CI}=0.69-0.89)\end{array}$ & & $\begin{array}{c}\text { Prostate cancer } \\
\text { risk } \\
\text { Prostate cancer } \\
\text { risk for } \\
\text { population- } \\
\text { basedcase- } \\
\text { control studies } \\
\text { Risk of } \\
\text { high-stage } \\
\text { advanced } \\
\text { prostate cancer }\end{array}$ \\
\hline & $(150)$ & $\begin{array}{c}\text { Meta-analysis } \\
\text { of studies }\end{array}$ & $\begin{array}{l}1294 \text { cases, } \\
11,492 \\
\text { controls }\end{array}$ & $\begin{array}{c}\text { Consumption } \\
\text { of cruciferous } \\
\text { vegetables }\end{array}$ & $(\mathrm{OR}=0.87,95 \% \mathrm{CI}=0.72-1.06)$ & & $\begin{array}{l}\text { Prostate cancer } \\
\text { risk }\end{array}$ \\
\hline & $(151)$ & & $\begin{array}{l}1,560 \text { cases, } \\
2,134 \\
\text { participants }\end{array}$ & $\begin{array}{l}\text { Post-diagnostic } \\
\text { consumption } \\
\text { of cruciferous } \\
\text { vegetables }\end{array}$ & $(\mathrm{HR}=0.41,95 \% \mathrm{CI}=0.22-0.76)$ & 0.003 & $\begin{array}{l}\text { Risk of } \\
\text { prostate cancer } \\
\text { progression }\end{array}$ \\
\hline Quercetin & (189) & $\begin{array}{c}\text { Large network } \\
\text { of case-control } \\
\text { studies }\end{array}$ & $\begin{array}{l}1294 \text { cases } \\
\text { and } 3094 \\
\text { controls }\end{array}$ & $\begin{array}{l}\text { Apple intake } \\
\geq 1 \text { apple/day }\end{array}$ & $(\mathrm{OR}=0.91,95 \% \mathrm{CI}=0.77-1.07)$ & & $\begin{array}{c}\text { Prostate cancer } \\
\text { risk }\end{array}$ \\
\hline Zinc & (236) & $\begin{array}{l}\text { Prospective } \\
\text { cohort study }\end{array}$ & $\begin{array}{c}35,242 \\
\text { men }\end{array}$ & $\begin{array}{l}10-\mathrm{yr} \\
\text { supplemental } \\
\text { zinc intake } \\
15 \mathrm{mg} / \text { day }\end{array}$ & $(\mathrm{HR}=0.34,95 \% \mathrm{CI}=0.13-1.09)$ & 0.04 & $\begin{array}{c}\text { Risk of } \\
\text { advanced } \\
\text { prostate cancer }\end{array}$ \\
\hline
\end{tabular}

case-control studies. For cooked tomatoes and sauces, the pooled RR was $0.63\left(95 \% \mathrm{CI}=0.40-1.00, p=0.052, I^{2}=69.1 \%\right)$ for case-control studies and $0.92(95 \% \mathrm{CI}=0.85-0.99, p=0.025$, $I^{2}=0 \%$ ) for cohort and nested case-control studies. For raw tomatoes, the pooled $\mathrm{RR}$ was $0.95(95 \% \mathrm{CI}=0.76-1.19$, $p=0.729, I^{2}=55.9 \%$ ) for case-control studies and 0.96 (95\% CI $\left.=0.81-1.14, p=0.557, I^{2}=60.6 \%\right)$ for cohort and nested case-control studies. The pooled RR for associations between tomato consumption and advanced prostate cancer was 0.89 $\left(95 \% \mathrm{CI}=0.77-1.03, p=0.113, I^{2}=35.3 \%\right.$. The pooled RR was $1.10\left(95 \% \mathrm{CI}=0.84-1.44, p=0.493, I^{2}=0 \%\right)$ for case-control studies and $0.81\left(95 \% \mathrm{CI}=0.68-0.97, p=0.019, I^{2}=16.3 \%\right)$ for cohort studies (84).

A systematic review and meta-analysis of prospective studies (11 cohort studies and 6 nested case-control studies) has reported inverse associations between intake of tomato/tomato products and lycopene and prostate cancer risk (86). However, the associations were all suggestive but not statistically significant. The pooled risk estimates of prostate cancer incidence among consumers of higher raw tomato and cooked tomato (which accounted for $82 \%$ of lycopene consumption) versus consumers of lower intakes were 0.81 $(95 \% \mathrm{CI}=0.59-1.10)\left(I^{2}=74 \%\right)$ and $0.85(95 \% \mathrm{CI}=0.69-1.06)$ $\left(I^{2}=64 \%\right)$, respectively. The effect-estimate found by increasing lycopene consumption was slightly higher than that of concentrations of serum lycopene; The odds ratio of higher versus lower lycopene consumption and serum lycopene were $0.93(95 \% \mathrm{CI}=0.86-1.01)\left(I^{2}=18 \%\right)$ and $0.97(95 \% \mathrm{CI}=0.88-$ 1.08) $\left(I^{2}=0 \%\right)$, respectively. Subgroup analysis demonstrated that the RR for advanced prostate cancer of combined consumption of both tomatoes and cooked tomato products (which accounted for $82 \%$ of lycopene intake) was 0.65 (95\%CI=0.44-0.95) for consumption frequency $>10$ versus $<1.5$ servings weekly. The odds ratio of the highest serum lycopene with the lowest in association with the risk of advanced prostate cancer was 0.77 (95\% CI=0.49-1.20) $\left(I^{2}=74 \%\right)(85)$. A meta-analysis of observational studies (11 case-control studies and 5 cohort studies and 5 nested casecontrol studies) has revealed that high intake of raw tomatoes and cooked tomato products, which provide the bulk of lycopene, decrease the risk of prostate cancer by $11 \%$ (RR high $v s$. low intake $=0.89 \quad(95 \% \mathrm{CI}=0.80-1.00)$ and $19 \%$ 
$(\mathrm{RR}=0.81(95 \% \mathrm{CI}=0.71-0.92)$, respectively. Importantly, the protective effect shown by increased serum or plasma concentrations of lycopene was higher than that of raw tomatoes or cooked tomato products intake; serum or plasma concentrations of lycopene were associated with $26 \%$ decrease of prostate cancer risk for all studies [high $v s$. low serum concentrations $\mathrm{RR}=0.74(95 \% \mathrm{CI}=0.59-0.92)], 45 \%$ for casecontrol studies $[\mathrm{RR}=0.55(95 \% \mathrm{CI}=0.32-0.94)]$ and $22 \%$ for cohort studies $[\mathrm{RR}=0.78(95 \% \mathrm{CI}=0.61-1.00)](86)$. A pooled analysis of 15 prospective studies $(11,239$ cases including 1,654 advanced-stage and 1741 aggressive, and 18,541 controls) has demonstrated that plasma level of lycopene was associated with lower risk of aggressive prostate cancer $(\mathrm{OR}=0.65$ (95\% CI=0.46-0.91; p-trend=0.032) (87). It should be noted that lycopene absorption can be influenced by numerous factors such as processing or cooking, the lipid content of the diet, and possibly genetic factors and therefore dietary evaluation of consumption of lycopene might not reflect its bioavailability (88). It should be noted that the magnitude of the correlations between intake of raw tomatoes with lycopene plasma level is modest and the bioavailability of lycopene has been reported to be higher from tomato products than raw tomatoes $(86,89,90)$. The above empirical approach based on plasma lycopene level avoids several assumptions about validity of responses for various co-occurring components, nutrient composition and portion sizes (91).

In dose-response analysis of the above-mentioned metaanalysis of thirty studies (24,222 cases and 260,461 participants), significant nonlinear dose-response association between total tomato consumption and prostate cancer was observed $\left(p_{\text {linear }}=0.099, p_{\text {nonlinear }}=0.017\right)$; Prostate cancer risk decreased by $13 \%$ at $200 \mathrm{~g} /$ week, $28 \%$ at $500 \mathrm{~g} /$ week, $46 \%$ at $1,000 \mathrm{~g} /$ week, and $56 \%$ for $1,350 \mathrm{~g} /$ week. Nevertheless, there was not any dose-response association between consumption of tomato foods and risk of prostate cancer ( $p_{\text {linear }}=0.400$, $p_{\text {nonlinear }}=0.173$ ). There was a significant dose-response association between cooked tomatoes and sauces and prostate cancer risk $\left(p_{\text {linear }}<0.001, p_{\text {nonlinear }}<0.001\right)$; Prostate cancer risk decreased by $3 \%$ for $60 \mathrm{~g} /$ week, $12 \%$ for $120 \mathrm{~g} /$ week, $19 \%$ for $240 \mathrm{~g} /$ week, and $49 \%$ for $420 \mathrm{~g} /$ week in the nonlinear model and decreased by $3.5 \%$ for each additional $30 \mathrm{~g} / \mathrm{week}$. A significant linear dose-response association was observed between raw tomatoes and prostate cancer risk $\left(p_{\text {linear }}=0.037\right.$, $\left.p_{\text {nonlinear }}=0.099\right)$; Prostate cancer risk decreased by $2 \%$ for each additional $100 \mathrm{~g}$ of raw tomatoes consumed per week (84). The most recent dose-response meta-analysis of twenty-six studies with 17,517 cases of prostate cancer reported from 563,299 participants has revealed that higher lycopene intake was associated inversely with risk of prostate cancer $(\mathrm{RR}=0.910$ (95\% CI $=0.819-1.011, p=0.078)$. [moderate heterogeneity $\left.\left(I^{2}=45.5 \%, p=0.037\right)\right]$. When one study was excluded and several sensitivity analyses were performed, the overall pooled risk estimates became more significant $(\mathrm{RR}=0.935,95 \% \mathrm{CI}=$
$0.881-0.993, p=0.030)$. [ $\left(I^{2}\right.$ changed from $45.5 \%$ to $\left.\left.0.0 \%\right)\right]$. The concentration of circulating lycopene between 2.17 and 85 $\mu \mathrm{g} / \mathrm{dL}$ was linearly inversely associated with prostate cancer risk $[\mathrm{RR}=0.821 \quad(95 \% \mathrm{CI}=0.711-0.949, \quad p=0.008)] \quad$ [little heterogeneity $\left.\left(I^{2}=16.9 \%, p=0.269\right)\right]$. When results were adjusted by the body mass index or age for studies with high quality and a follow-up period $>10$ years, the circulating lycopene concentration was more effective in preventing prostate cancer. Dose-response analysis indicated that each 5 $\mathrm{mg}$ /day increase of lycopene consumption decreased the risk of prostate cancer with $\mathrm{RR} 0.975[\mathrm{RR}=0.975$ (95\%CI $=0.940$ $1.010, p=0.160)$ ] for all studies. [moderate heterogeneity $\left.\left(I^{2}=50.2 \%, p=0.020\right)\right]$. When several sensitivity analyses were performed and one study removed, each $5 \mathrm{mg} /$ day increase of lycopene intake decreased the risk of prostate cancer with pooled risk estimate $(\mathrm{RR}=0.979,95 \% \mathrm{CI}=0.962-0.996, p=0.017)$ [ $\left(I^{2}\right.$ changed from $50.2 \%$ to $\left.\left.0.0 \%\right)\right](92)$. A dose-response metaanalysis of 34 studies (10 cohorts, 13 case-control studies and 11 nested case-control) involving 15,891 cases and 592,479 participants has revealed that lycopene dietary intake and its blood concentrations were both significantly associated with reduced risk of prostate cancer, $(\mathrm{RR}=0.86,95 \% \mathrm{CI}=0.75-0.98)$ and $(\mathrm{RR}=0.81,95 \% \mathrm{CI}=0.69-0.96)$, respectively. Dose-response analysis has found that risk of prostate cancer was reduced by $3 \%$ per $1 \mathrm{mg} /$ day $(95 \% \mathrm{CI}=0.94-0.99)$ increment of dietary lycopene consumption (93). The most recent and comprehensive dose-response meta-analysis of forty-two studies (43,851 cases, 692,012 participants) has demonstrated that both dietary high-lycopene intake and circulating lycopene concentrations were significantly associated with reduced prostate cancer risk, $(\mathrm{RR}=0.88,95 \% \mathrm{CI}=0.78-0.98, p=0.017)$ and $(\mathrm{RR}=0.88,95 \% \mathrm{CI}=0.79-0.98, p=0.019)$, respectively. When stratified by study design, case-control studies have indicated even a greater reduced prostate cancer risk with high-lycopene intake (pooled $\mathrm{RR}=0.82(95 \% \mathrm{CI}=0.68-0.999, p=0.049)$. There was a trend for chemoprevention against prostate cancer aggressiveness $\quad(\mathrm{RR}=0.74,95 \% \mathrm{CI}=0.55-1.00, p=0.052)$. Sensitivity and dose-response analyses revealed a significant linear dose-response and that prostate cancer risk decreased by $1 \%$ for every additional $2 \mathrm{mg}$ of lycopene consumed $(p=0.026)$. For each additional $10 \mu \mathrm{gdl}-1$ of circulating lycopene, prostate cancer risk decreased by 3.5 to $3.6 \% \quad\left(p_{\text {linear }}=0.004\right.$, $\left.p_{\text {nonlinear }}=0.006\right)(94)$.

As a final point, when the joint effect between lycopene and green tea consumption was investigated, interaction analysis showed that the chemoprotective effect from green tea and lycopene intake was synergistic and stronger than either agent alone $(p<0.01)$ (65). Intriguingly, compared with other chemopreventive compounds, a recent meta-analysis of 13 studies involving 3,020 patients has reported that lycopene exerts superior chemopreventive effects than most of other chemopreventive compounds including Dutasteride with the exception of green tea catechins (95). 
Table II. Summary of the mechanisms of action of phytochemicals selected in our review with associated signalling pathways in prostate cancer chemoprevention.

\begin{tabular}{|c|c|c|}
\hline Micronutrient & $\begin{array}{l}\text { Reference(s) } \\
\text { Study Author(s) } \\
\text { (year) (Ref.) }\end{array}$ & Main mechanism of action and key signalling pathways involved \\
\hline Lycopene & $(76-80)$ & $\begin{array}{l}\text { Induction of cell cycle arrest at } \mathrm{G}_{0}-\mathrm{G}_{1} \\
\text { Modulation of expression of CDK7, EGFR, IGF-1R and BCL2 } \\
\text { Modulation of cki-cyclin-cdk machinery } \\
\text { Activation of PPAR } \gamma \text {-LXR } \alpha \text {-ABCA1 pathway } \\
\text { Protection of DNA, lipoproteins and intercellular gap junction communication }\end{array}$ \\
\hline $\begin{array}{l}\text { Epigallocatechin-3-gallate } \\
\text { (EGCG) }\end{array}$ & $(110,114-122)$ & $\begin{array}{l}\text { Induction of cell-cycle arrest } \\
\text { Induction of apoptosis } \\
\text { Induction of ROS } \\
\text { Inhibition of clonal expansion of prostate cancer stem cells } \\
\text { Inhibition of NF-kB, HER-2/neu, (IGF-1)-mediated and EGF-mediated signalling pathways } \\
\text { Inhibition of proteasome activity, iNOS, MMPs, VEGF, AP-1, MAPKs and COX2 expression } \\
\text { Epigenetic modulation of (hTERT) expression }\end{array}$ \\
\hline Indole-3-carbinol & $(124-127)$ & $\begin{array}{l}\text { Induction of cell cycle arrest at } \mathrm{G}_{1} / \mathrm{S} \\
\text { Induction of apoptosis } \\
\text { Up-regulation of p27, p21, p15 and Bax } \\
\text { Down-regulation of CDK2, CDK4, CDK6, cyclin D1, cyclin E, FLIP, IAP, XIAP, } \\
\text { Bcl-2, Bcl- } \mathrm{X}_{\mathrm{L}} \text { and survivin } \\
\text { Activation of cas-9 and cas-3 } \\
\text { Induction of expression of TRAIL death receptor DR4 and DR5 } \\
\text { Inhibition of clonal expansion of prostate cancer stem cells } \\
\text { Inhibition of NF-KB, Nrf2, oestrogen and androgen receptors signalling pathways } \\
\text { Modulation of epigenetic alterations such as histone modification, CpG methylation } \\
\text { and aberrant expression of microRNA }\end{array}$ \\
\hline Sulforaphane & $(128-136)$ & $\begin{array}{l}\text { Induction of cell cycle arrest at } \mathrm{G}_{2} / \mathrm{M} \\
\text { Inhibition of cyclin } \mathrm{D} 1 \text { and } \mathrm{Bcl}-\mathrm{X}_{\mathrm{L}} \text { expression } \\
\text { Phosphorylation of ERK1/2 and JNK1/2 } \\
\text { Inhibition of the nuclear translocation of p } 65 \text { and IKK } \alpha / \beta-\mathrm{IkB} \alpha-\mathrm{p} 65 \text { signalling pathway } \\
\text { Inhibition of NF-KB activity and NF-kB-regulated VEGF } \\
\text { Activation of (ARE) elements } \\
\text { Induction of HO-1 expression and Nrf2 accumulation } \\
\text { Promotion of phase II enzyme expression } \\
\text { Disruption of signalling within tumour microenvironments } \\
\text { Inhibition of histone deacetylase activity }\end{array}$ \\
\hline Resveratrol & $\begin{array}{c}(156-162) \\
(122,163-169) \\
(170-175)\end{array}$ & $\begin{array}{l}\text { Suppression of ROS and RNS production } \\
\text { Induction of HO-1 via ARE-mediated transcriptional activation of Nrf2 } \\
\text { Inhibition of hypoxia-inducible factor-1 } \alpha \text {-mediated androgen receptor signalling } \\
\text { Up-regulation of MKP5 } \\
\text { Inhibition of JNK, p38, cytokine-induced NF-kB activation, COX2 expression, IL-6 and IL-8 } \\
\text { Disruption of signalling pathways triggered by IL1- } \beta \\
\text { Inhibition of cyclin B and Cdk1 expression and cyclin B/Cdk1 kinase activity } \\
\text { Modulation of c-Fos, c-Jun, AP-1 and NF-kB, VEGF, MMPs } 2 / 9 \text {, Bcl-2, Bcl-XL Bax, } \\
\text { Bak, PUMA, Noxa, TRAIL, APAF, Akt, p53, Rb, p21, p27 cyclins, CDKs, ATM/ATR } \\
\text { Promotion of acetylation } \\
\text { Regulation of microRNAs expression and chromatin modifier (MTA1) } \\
\text { Down-regulation of expression of androgen receptor and oestrogen receptor } \\
\text { alpha-dependent phosphoinositide-3-kinase PI3K } \\
\text { Inhibition of } \beta \text {-catenin-mediated androgen receptor function }\end{array}$ \\
\hline Quercetin & $(182-187)$ & $\begin{array}{l}\text { Induction of TRAIL-mediated apoptosis } \\
\text { Inhibition of expression of several oncogenes and restoration of tumour suppressor genes } \\
\text { Reverse epigenetic alterations associated with inactivation of tumour suppressor } \\
\text { genes and activation of oncogenes } \\
\text { Reducing (IGFs) via induction of (IGFBP-3) } \\
\text { Inhibition of prostate cancer stem cells via the PI3K/Akt and MAPK/ERK signalling pathways }\end{array}$ \\
\hline
\end{tabular}

Table II. Continued 
Table II. Continued

\begin{tabular}{|c|c|c|}
\hline Micronutrient & $\begin{array}{l}\text { Reference(s) } \\
\text { Study Author(s) } \\
\text { (year) (Ref.) }\end{array}$ & Main mechanism of action and key signalling pathways involved \\
\hline Curcumin & $\begin{array}{c}(160,161) \\
(117,197-205)\end{array}$ & $\begin{array}{l}\text { Up-regulation of MKP5 } \\
\text { Down-regulation of inhibitor of DNA binding } 1 \text { by small interfering RNA } \\
\text { Restoration of tumour suppressor p53 } \\
\text { Activation of Nrf2 signalling } \\
\text { Down-regulation of VEGF expression } \\
\text { Modulation of (TLR/IL-1R) pathway } \\
\text { Transformation of TGF- } \beta 1 \\
\text { Modulation of iNOS and COX2 } \\
\text { Promotion of apoptosis by down-regulating Bcl-2 and up-regulating Bax } \\
\text { Suppression of MMP9 } \\
\text { Modulation of NF-kB, PI3K/Akt/mTOR, MAPK, JAK/STAT signalling } \\
\text { Inhibition of ROS production } \\
\text { Inhibition of expression of (CXCR4) and (IL-6) receptors via } \\
\text { MAOA/mTOR/HIF- } 1 \alpha \text { signalling } \\
\text { Modification of chromatin landscape and suppression of histone acetylation } \\
\text { Suppression of coactivator protein p300 and element-binding protein occupancy } \\
\text { at sites of androgen receptor function }\end{array}$ \\
\hline Piperine & $(221,222)$ & $\begin{array}{l}\text { Induction of cell cycle arrest at } \mathrm{G}_{0} / \mathrm{G}_{1} \\
\text { Induction of apoptosis } \\
\text { Up-regulation of p21 and p27 } \\
\text { Down-regulation of cyclin D1, cyclin A and phosphorylated STAT-3 } \\
\text { Inhibition of expression of NF-kB transcription factor } \\
\text { Promotion of autophagy }\end{array}$ \\
\hline Zinc & $(231,232)$ & $\begin{array}{l}\text { Induction of cell cycle arrest } \\
\text { Induction of apoptosis } \\
\text { Activation of caspases } \\
\text { Targeting Bcl-2-like and Bax-like mitochondrial membrane proteins } \\
\text { Inhibition of conversion of testosterone to dihydrotestosterone }\end{array}$ \\
\hline
\end{tabular}

\section{Epigallocatechin gallate (EGCG)}

Green tea has been extensively investigated for its protective role against various types of human cancers including prostate cancer (96). The inhibitory action of green tea on carcinogenesis was attributed to its active compounds present in higher amounts called polyphenols which consist mainly of catechins, especially epigallocatechin-3-gallate (EGCG) which accounts for more than $50 \%$ of total polyphenols $(97,98)$. Short-term intervention with green tea has been shown to increase the levels of epigallocatechin gallate (EGCG) in prostate tissues supporting its prostate-specific bioavailability; Both methylated and nonmethylated forms of EGCG have been detected in prostatectomy tissues from patients who have been consuming 6 cups green tea per day for 3-8 weeks compared to samples from patients consuming water (99). Analogously, a randomised clinical trial has shown uptake of green tea polyphenols by prostate tissue and evidenced their induced changes in systemic oxidation and nuclear factor-kB (NF-kB); Both urinary 8-Hydroxy-2-deoxyguanosine $(8 \mathrm{OHdG})$ and $\mathrm{NF}-\mathrm{kB}$ in radical prostatectomy tissue have been found to be statistically significantly reduced in men consuming 6 cups/day for 3-8 weeks of green tea $(p=0.013)$ compared to individuals consuming water (100).

Despite the fact that clinical evidence is still sparse with regard to EGCG, numerous epidemiological studies have demonstrated lower incidence of prostate cancer in Asian populations where consumption of green tea is high and regular as compared to Western countries (27). A metaanalysis of thirteen observational studies in Asian populations has documented a moderately significant inverse association between green tea intake and prostate cancer risk $(\mathrm{OR}=0.62$; $95 \% \mathrm{CI}=0.38-1.01)$. When analyses were stratified by study design, the pooled estimate reached a more statistically significant level for case-control studies $(\mathrm{OR}=0.43$; 95\%CI=0.25-0.73) (101). Similarly, the stratified analyses of an updated meta-analysis of 21 studies has shown a protective effect for tea intake against prostate cancer in 18 case-control studies $(\mathrm{OR}=0.77,95 \% \mathrm{CI}=0.55-0.98)(102)$. A pooled analysis of 21 studies (104) has shown that total consumption of tea (both green and black) was significantly associated with reduced prostate cancer risk $(\mathrm{OR}=0.84,95 \% \mathrm{CI}=0.71-0.98)$ 
(104). Importantly, subgroup analyses showed that consumption of tea significantly reduced risk of prostate cancer in China and India, $(\mathrm{OR}=0.40$ and, $95 \% \mathrm{CI}=0.25-0.66)$ and $(\mathrm{OR}=0.48,95 \% \mathrm{CI}=0.24-0.97)$, respectively. In stage subgroup analyses, the highest level of tea intake was associated with a significant protective effect on low-grade prostate cancer $(\mathrm{OR}=0.66,95 \% \mathrm{CI}=0.46-0.93)(103)$.

More importantly, several studies have demonstrated that green tea is an effective chemopreventive agent, predominantly in prostate cancer patients with high-grade prostate intraepithelial neoplasia. In high-grade intraepithelial neoplasia patients, green tea catechins showed superiority in decreasing prostate cancer in high-grade intraepithelial neoplasia patients over all other natural chemoprevention agents. A systematic review and stratified analyses of observational studies and randomised controlled trials (RCTs) using stringent inclusion criteria, namely Newcastle-Ottawa Scale (NOS) and the Jadad scale as quality assessment tools, have concluded that green tea is an effective chemopreventive agent, particularly in prostate cancer patients with high-grade prostate intraepithelial neoplasia (104). A subgroup analysis of a recent meta-analysis comprised 13 studies involving 3,020 patients has reported that green tea catechins significantly decreased prostate cancer in high-grade intraepithelial neoplasia patients $(\mathrm{RR}=0.39,95 \% \mathrm{CI}=0.16-10.97$, $p=0.044)$, with moderate heterogeneity $\left(I^{2}=47.9 \%, \mathrm{x}^{2}=1.92\right.$, $p=0.166$ ) (95). Furthermore, a recent meta-analysis has reported that green tea catechins had a significant protective effect against prostate cancer $(\mathrm{RR}=0.38(95 \% \mathrm{CI}=0.16-0.86, p=0.02)$, particularly in patients with high-grade prostatic intraepithelial neoplasia disease or atypical small acinar proliferation (105). Men with high-grade intraepithelial neoplasia, which is the most established precursor of prostate cancer, are at high-risk for prostate cancer as they have a $30 \%$ chance of developing prostate cancer within a year of detection. The fact that highgrade intraepithelial neoplasia manifests similar cytological features to prostate cancer and is considered easily identifiable makes it an invaluable candidate for chemopreventive interventions $(98,106)$.

In order to quantitatively evaluate the association of green tea consumption with prostate cancer risk, a dose-response analysis of a case-control study involving 253 patients with prostate cancer and 419 controls has shown that habitual total tea consumption was associated with lower risk of prostate cancer; Relative to participants drinking $<100 \mathrm{ml} /$ day, the adjusted odds ratios were $0.52(95 \% \mathrm{CI}=0.35-0.79)$ and 0.30 (95\% CI=0.18-0.48) for participants drinking 100-500 ml/day and $>500 \mathrm{ml} /$ day, respectively $(107)$. The most recent doseresponse meta-analysis of seven observational studies and three randomised controlled trials has reported an inverse association between consumption of green tea and prostate cancer risk with a linear dose-response effect (106). Consumption of more than 7 cups per day of green tea was linearly associated with a statistically significant reduced prostate cancer risk $(\mathrm{RR}=0.81 \quad(95 \% \mathrm{CI}=0.67-0.97)$. When subgroup analysis was conducted by study design, the casecontrol studies demonstrated a stronger protective effect of green tea consumption against prostate cancer $(\mathrm{R} R=0.453$, $95 \% \mathrm{CI}=0.249-0.822$ ) and that the approximate RR for each 1 cup per day increase of green tea was 0.893 , (95\% CI $=0.796-$ $1.002, p=0.054)$ (105). A large prospective study involving 49,920 men has demonstrated that green tea consumption was correlated with a dose-dependent decrease of advanced prostate cancer risk ( $<1$ cup/day: reference; 3-4 cups/day: $\mathrm{RR}=0.86,95 \% \mathrm{CI}=0.50-1.47 ; \geq 5$ cups/day: $\mathrm{RR}=0.60$, $\left.95 \% \mathrm{CI}=0.34-1.06 ; \quad p_{\text {trend }}=0.03\right)$. When all potential confounding factors were adjusted, the inverse association was strengthened to statistical significance (highest $v s$. lowest $\mathrm{RR}=0.52,95 \% \mathrm{CI}=0.28-0.96)\left(p_{\text {trend }}=0.01\right)(31)$. Similarly, a placebo-controlled, double-blinded, randomised clinical trial of a mix of catechins containing $400 \mathrm{mg}$ EGCG per day for 1 year in 97 men with high-grade prostatic intraepithelial neoplasia and/or atypical small acinar proliferation prostate disease has reported a reduction in atypical small acinar proliferation prostate disease, which is associated with prostate cancer, observed in $11.5 \%$ of patients in the intervention group versus $40 \%$ in the control group $(p=0.024)(109)$. There was also a significantly greater decrease in serum levels of PSA in the intervention group in comparison with the control group $(p=0.029)[-0.87 \mathrm{ng} / \mathrm{ml} ; 95 \% \mathrm{CI}=-1.66$ to -0.09$]$ with no significant adverse events between both groups (108). In patients with high-grade prostatic intraepithelial neoplasia and precancerous lesions, supplementation with green tea catechins was associated with lower prostate cancer incidence, reduced PSA level, delay in the onset of prostate cancer, reduced lower urinary tract symptoms and further improvement in quality of life (a total of $600 \mathrm{mg}$ daily of green tea catechins). After a one-year follow-up, there was only $3 \%$ incidence in the green tea catechins group compared to $30 \%$ in the placebo group $(p<0.01)$, suggesting a $90 \%$ chemopreventive effect of green tea catechins. There was also a significant decrease in International Prostate Symptom Score in the green tea catechins group compared to placebo group with no significant adverse effects. After a two-year followup, further reduction in prostate cancer incidence was observed suggesting a long-lasting effect of green tea catechins; 2 of the 9 placebo men and only 1 of the 13 the green tea catechins patients were diagnosed with prostate cancer, indicating an $80 \%$ decrease in diagnosis of prostate cancer in patients with high-grade prostatic intraepithelial neoplasia $(98,109)$.

The mechanisms by which EGCG exerts its anticancer potential comprise modulating multiple cellular signalling pathways involved in inflammation, angiogenesis, metastasis and invasion in both androgen-dependent and androgenindependent human prostate cancers (110). Prostate cancers that do not respond to hormonal treatment, which is the therapeutic 
mainstay for patients with prostate cancer, eventually become androgen-independent and therefore refractory to anti-androgen therapeutics leading to cancer recurrence $(15,64)$.

Multiple studies have demonstrated that EGCG can regulate androgen activity in target organs and induce significant changes in several endocrine parameters as well as inhibit the prostatic enzyme that transforms testosterone into 5- $\alpha$ dihydrotestosterone, namely 5 - $\alpha$-reductase $(111,112)$. A small trial involving twenty-six men with prostate cancer scheduled for radical prostatectomy has also reported that short-term supplementation with EGCG had significantly reduced serum levels of biomarkers such as PSA, vascular endothelial growth factor (VEGF) and hepatocyte growth factor (HGF) (113). These results support a possible role for EGCG in the prevention of prostate cancer. Furthermore, numerous experiments have revealed that EGCG can inhibit clonal expansion of cancer stem cells, cyclo-oxygenase-2 (COX-2) overexpression, proteasome activity, inducible nitric oxide synthase (iNOS), matrix metalloproteinases (MMPs), vascular endothelial growth factor (VEGF) and activator protein 1 (AP1) and MAPKs (115-117). Along with inhibition of HER2/neu signalling, EGCG has been shown to inhibit both insulin-like growth factor-1 (IGF-1)-mediated signalling, nuclear factor- $\mathrm{kB}$ and EGF-mediated transduction signalling pathways, modulate cyclin kinase inhibitor (CKI)-cyclincyclin-dependent kinase (CDK) machinery, and multiple reversible epigenetic mechanisms $(110,114-116)$. Data from in vitro and in vivo studies have revealed that green tea polyphenols can trigger apoptosis in cancerous cells via the epigenetic modulation of the expression of apoptosisassociated genes including human telomerase reverse transcriptase (hTERT) and/or induction of reactive oxygen species (ROS) $(117,118)$. Although certain phytochemicals such as green tea (EGCG), resveratrol and curcumin display antioxidant and anti-ROS activities, there is ample evidence that these phytochemicals can also exert pro-oxidant activity particularly in the presence of redox active transition ions leading to production of ROS and oxidative DNA and proteins damage resulting in cell cycle arrest or apoptotic cell death (119-122). This pro-oxidant action represents a vital pathway via which transformed cells are preferentially targeted by such phytochemicals whereas normal cells survive.

\section{Indole-3-Carbinol \& Sulforaphane}

Because Mediterranean diet and dietary patterns rich in vegetables and fruits have been associated with significantly reduced all-cause mortality and may reduce prostate cancer risk by up to $75 \%(38,42,52)$, phytochemicals that are present at high levels in vegetables and fruits have been extensively investigated to explore their chemopreventive properties against prostate cancer. Cruciferous vegetables contain high levels of glucosinolates, whose major breakdown product, by the action of myrosinase enzymes, is indole-3carbinol. Both in vitro and in vivo experimental studies have shown that indole-3-carbinol exhibits potent anticarcinogenic properties against prostate cancer (123). Indole-3-carbinol has been shown to exert robust cancer-preventive properties primarily via its ability to selectively induce $G_{1} / S$ arrest of the cell cycle and apoptosis in cancer cells, which are considered key processes in the prevention of tumour growth $(124,125)$. The cell-cycle arrest by indole-3-carbinol involves upregulation of p27, p21, p15, and down-regulation of cyclindependent kinases CDK2, CDK4, and CDK6, and cyclin D1 and cyclin E. Apoptosis induced by indole-3-carbinol involves activation of cas-9 and cas-3, release of mitochondrial cytochrome $\mathrm{C}$, up-regulation of proapoptotic protein Bax, down-regulation of antiapoptotic gene products such as Fasassociated death domain protein-like interleukin-1-betaconverting enzyme inhibitory protein (FLIP), inhibitor-ofapoptosis protein (IAP), X chromosome-linked IAP (XIAP), Bcl-2, Bcl-xL and survivin. In addition to its ability to potentiate the effects of tumour necrosis factor-related apoptosis-inducing ligand (TRAIL), indole-3-carbinol inhibits the activation of nuclear factor-kappa $\mathrm{B}(\mathrm{NF}-\mathrm{kB})$, oestrogen receptor signalling, androgen receptor signalling and nuclear factor-E2-related factor 2 (Nrf2) (126). Recently, indole-3carbinol has been found to target cancer stem cells and modulate epigenetic alterations including histone modification, CpG methylation and aberrant expression of microRNA (127).

Another phytochemical that occurs ubiquitously in cruciferous vegetables is an isothiocyanate called Sulforaphane. It has been reported that Sulforaphane can induce $\mathrm{G}_{2} / \mathrm{M}$ cell-cycle arrest and influence human prostate cancer development and progression via disruption of signalling within tumour microenvironments and activation of apoptotic cell death $(128,129)$. In addition to its inhibition of the nuclear translocation of p65 and IKK $\alpha / \beta$-IKB $\alpha$-p65 signalling pathway in prostate cancer cells, sulforaphane has been reported to strongly inhibit NF- $\mathrm{kB}$ activity and NF-kBregulated VEGF, cyclin D1, and Bcl-XL gene expression (130, 131). Moreover, sulforaphane and other isothiocyanates have been found to activate ERK1/2 and JNK signalling pathway resulting in phosphorylation of Nrf2 and its translocation to the nucleus which in turn activates ARE elements and induces expression of stress-responsive genes, including $\mathrm{HO}-1$. Nuclear Nrf2 (132). Additionally, in vitro and in vivo studies have reported that sulforaphane can potently increase phase II enzyme expression; Loss of phase II enzyme expression occurs early and almost universally in prostate cancer (133, 134). In animal models, sulforaphane has also been shown to target epigenetic events that can occur at various stages of carcinogenesis and metastasis including inhibition of histone deacetylase activity in benign prostate hyperplasia and both androgen-dependent and androgen-independent prostate cancer cells $(135,136)$. 
It seems that the mechanisms of the anticarcinogenic effects of cruciferous vegetables involve the early rather than the later stages of carcinogenesis $(137,138)$. In a double-blinded, randomised placebo-controlled multicentre trial, 78 prostate cancer patients who had rising levels in PSA after radical prostatectomy were treated with either $60 \mathrm{mg}$ sulforaphane or placebo for 6 months and then followed for 2 months with no treatment. PSA increased significantly $>20 \%$ in the placebo group (71.8\%) compared with the sulforaphane group $(44.4 \%$, $p=0.0163$ ). Also, the doubling time of PSA was $86 \%$ longer in the sulforaphane compared with the placebo group (28.9 and 15.5 months, respectively (139). PSA plays a key role in prostate tumour growth mainly via regulating numerous proangiogenic and anti-angiogenic growth factors. Despite its low sensitivity, PSA is the key marker for prostate cancer risk including high-grade tumours and therefore interventions that aim to inhibit its production in the prostate might have a beneficial role in prevention of prostate cancer. Elevated PSA serum levels reflect not only the presence of cancer but also chronic inflammation in the prostate which may enhance prostate carcinogenesis and induce a further elevation of PSA level (140). In addition to its utility as a clinical biomarker for prostate cancer diagnosis, prognosis, progression and response to therapy $(141,142)$, PSA levels have been widely used as an established continuous variable to define risk categories in prostate cancer chemoprevention studies (143-148).

Numerous epidemiological studies investigating associations between consumption of cruciferous vegetables and risk of cancer have confirmed that the high intake of cruciferous vegetables has advantageous effects on the risk of various common cancers including prostate cancer. This protective effect is largely attributed to the presence of sulforaphane and Indole-3-carbinol. Analysis of a network of Italian and Swiss case-control studies $(10,000$ cases with 1294 prostate cancer cases and 17,000 controls) has reported an inverse association between consumption of vegetables and fruits in the risk of various common cancers including the prostate $\mathrm{OR}=0.9$. The OR for cruciferous vegetables and prostate cancer risk was 0.87 (for the highest $\mathrm{v}$. the lowest levels of consumption of cruciferous $\geq 1 v s .<1$ portion/week) $(\mathrm{OR}=0.87,95 \% \mathrm{CI}=0.70$ 1.09) (51). The first meta-analysis of 13 studies (seven were cohort and six population-based case-control studies) evaluating the association between consumption of cruciferous vegetables and prostate cancer risk has found that high consumption of cruciferous vegetables was significantly associated with $10 \%$ decreased risk of prostate cancer $(\mathrm{RR}=0.90,95 \% \mathrm{CI}=0.85-0.96)$ in all studies and $21 \%$ decreased risk of prostate cancer in population-based case-control studies $(\mathrm{RR}=0.79 ; 95 \% \mathrm{CI}=0.69-0.89)$. Interestingly, the inverse relationship was stronger for high-stage advanced disease ( $\mathrm{RR}=0.69 ; 95 \% \mathrm{CI}=0.53-0.86$ ) (149). Another meta-analysis of studies conducted over 18 years in Europe including a total of 1294 of prostate cancer patients and 11,492 controls has shown that consumption of cruciferous vegetables was associated with a $13 \%$ reduction in prostate cancer risk $(\mathrm{OR}=0.87$, $95 \% \mathrm{CI}=0.72-1.06$ ) (150). Furthermore, a study involving 1,560 cases and 2,134 participants has found that post-diagnostic consumption of cruciferous vegetables was associated with a $59 \%$ reduced risk of prostate cancer progression $(\mathrm{HR}=0.41$, $95 \% \mathrm{CI}=0.22-0.76 ; p$-trend $=0.003)(151)$.

It should be noted that consumption of cruciferous vegetables might not always be a practical way to obtain the daily required quantities of sulforaphane and Indole-3carbinol; Concentration of sulforaphane and Indole-3-carbinol in cruciferous vegetables is highly variable depending on various factors including the amount of sunlight, soil, rainfall, seed strain and myrosinase enzyme activity. Therefore, particularly for Indole-3-carbinol, semisynthetic sources and extracts of cruciferous vegetables are considered to be more practical (123).

\section{Resveratrol}

Resveratrol, a naturally occurring polyphenolic phytoalexin that is present in grapes and berries, has various health benefits, particularly the mitigation of age-related diseases and carcinogenesis $(152,153)$. It has been shown that resveratrol can inhibit the promotion and growth of several cancers including the prostate $(154,155)$. It has been shown that resveratrol exerts potent anti-initiation, anti-promotion and antiprogression activities throughout the multi-stage process of carcinogenesis (153). Resveratrol can augment cellular antioxidant defence capacity and sensitise prostate cancer cells to treatment through reducing both undesired basal reactive oxygen species (ROS) and reactive nitrogen species (RNS) as well as inducing antioxidant enzymes such as heme-oxygenase1 (HO-1) through ARE-mediated transcriptional activation of Nrf2 (156-158). In addition to its inhibition of COX-2 expression, resveratrol has been found to interfere with proinflammatory signalling pathways triggered by IL $1-\beta$ leading to inhibition of inflammation, which is often involved in cancer onset and progression by regulating proliferation, apoptotic cell death and angiogenesis (159). Pro-inflammatory mediators such as cyclooxygenase-2 (COX2) have been reported to enhance carcinogenesis as their aberrant expression was observed in both premalignant and malignant human tumours including prostate cancer $(160,161)$. Furthermore, resveratrol has been shown to induce a potent anti-inflammatory mediator, namely MAP kinase phosphatase-5, resulting in inhibition of both JNK and the stress-activated protein kinase p38 in prostate cancer cells. The latter is known to regulate pro-inflammatory responses and its inhibition results in reduced pro-inflammatory cytokine release, cytokine-induced $\mathrm{NF}-\mathrm{kB}$ activation, $\mathrm{COX}-2$ expression, IL-6 and IL-8 (162).

Other verified mechanisms associated with cancer-preventing and anti-cancer effects of resveratrol on human cancer cells 
include modulation of i) transcription factors c-Fos, c-Jun, AP1 and NF-kB, ii) angiogenic and metastatic factors, VEGF and matrix metalloprotease $2 / 9$, iii) apoptotic and survival regulators, Bcl-2, Bcl-XL Bax, Bak, PUMA, Noxa, TRAIL, Apoptotic Protease Activating Factor (APAF) and Protein kinase B (Akt), iv) tumour suppressors p53 and Rb; cell cycle regulators, p21 and p27 cyclins, CDKs and the checkpoint kinases ATM/ATR (123, 164-170), v) epigenetic mechanisms such as promotion of acetylation, reactivation of PTEN tumour suppressor and posttranslational modifications leading to inhibition of the Akt pathway (170) and vi) post-translational modifications and regulation of microRNAs expression and chromatin modifier metastasis-associated protein 1 (MTA1) (171). Resveratrol ability to decrease cyclin $\mathrm{B} / \mathrm{Cdk} 1$ kinase activity and cyclin B and Cdk1 expression was observed in both androgen-sensitive and androgen-insensitive prostate cancer cells (172). In addition to its anti-androgenic properties through its ability to downregulate the expression of androgen receptor (173), resveratrol has been found to down-regulate the expression of both androgen receptor and oestrogen receptor alpha-dependent phosphoinositide-3-kinase PI3K in prostate cancer cells (174). In castration-resistant prostate cancer, resveratrol can inhibit hypoxia-inducible factor- $1 \alpha$-mediated androgen receptor signalling and thus inhibit $\beta$-catenin-mediated androgen receptor function, which is driving both primary and recurrent disease (175). Approximately $90 \%$ of prostate cancer patients who respond to androgen deprivation therapy undergo rapid progression and become castration-resistant prostate cancer patients, which remains an incurable disease (15).

Although no human clinical trial has been performed to assess the preventative effects of resveratrol specifically on prostate cancer, data from a few small studies support its advantageous use in prostate cancer prevention. A 4-month randomised placebo-controlled clinical trial was conducted to assess the effects of resveratrol on seventy-six middle-aged men with metabolic syndrome, which is associated with the development, progression and worse oncological outcomes of several neoplasms including prostate cancer (176). The trial has determined that administration of a high dose of resveratrol (1000 $\mathrm{mg} / \mathrm{d})$ for 4 months significantly decreased serum levels of the androgen precursors androstenedione $24 \%$ $(p=0.052)$, dehydroepiandrosterone (DHEA) $41 \%(p<0.01)$, and dehydroepiandrosterone-sulphate (DHEAS) $50 \%$ $(p<0.001)$, compared to the control group. While an optimal dose of resveratrol in primary chemoprevention settings has not yet been determined, longer-term supplementation has greater effects (177). A single-arm phase I study in men with biochemically recurrent prostate cancer $(n=14,71 \%$ Caucasian, 29\% black) with a median follow-up of 19.2 (6.229.7) months has demonstrated that a resveratrol-rich muscadine-grape skin extract extended doubling time of PSA by 5.3 months (178). Interestingly, combinations of resveratrol with other micronutrients, such as quercetin, curcumin and epigallocatechin gallate, have been found to have greater inhibitory activities against diverse cancer models than either of these agents alone (179-181).

\section{Quercetin}

Quercetin, which is a bioactive flavonol pigment that is present at high concentrations in apples and onions, has been shown to exhibit inhibitory activities in various stages of tumour development. In addition to its potent antioxidant properties, quercetin's cancer-protecting effects mainly derive from promoting TRAIL-mediated cancer cell apoptosis and targeting several key oncogenic signalling transducers resulting in inhibition of expression of oncogenes and restoration of tumour suppressor genes (182-184). Quercetin has also reported to reverse epigenetic alterations associated with inactivation of tumour suppressor genes and activation of oncogenes (185). Moreover, quercetin has been found to reduce the insulin-like growth factors (IGFs) via increasing binding protein-3 (IGFBP3 ) resulting in induction of apoptosis in human prostate cancer cells (186). Further, recent evidence has demonstrated that quercetin can inhibit prostate cancer stem cells via the PI3K/Akt and MAPK/ERK signalling pathways (187).

The potential of consumption of apples in prostate cancer prevention has long been recognised and was largely attributed to the presence of quercetin. A small hospital based casecontrol study (50 case and 100 controls) has reported a significant inverse association between apple intake and prostate cancer risk ( $\mathrm{p}$ trends 0.01) (188). Data from a large network of case-control studies (1294 cases and 3094 controls) showed an inverse association between apple intake, $\geq 1$ apple/day, and prostate cancer risk (95\% CI=0.77-1.07) (189). Further, a meta-analysis of data from a network of Italian and Swiss case-control studies (10,000 cases with 1294 prostate cancer cases and 17,000 controls) has indicated that subjects who consumed at least one apple a day had a reduced risk of various common cancers including prostate cancers, $\mathrm{OR}=0.91(95 \% \mathrm{CI}=0.77-1.07)(51)$.

Finally, while repeated intake of quercetin was reported to lead to a build-up of the concentration in plasma, flavonols are bound to glycosides and their absorption from the diet is regarded to be negligible. As no enzymes can split the predominantly $\beta$-glyosidic bonds between flavonols and glycosides molecules found in intestinal lumen, only free flavonols without glycosides molecules, the so-called aglycones, are capable of passing the gut wall $(190,191)$.

\section{Curcumin \& Piperine}

Curcumin is the most bioactive polyphenolic isoflavone of the rhizome of the plant Curcumin longa known as turmeric which has been renowned for its anti-inflammatory and anticancer proprieties $(192,193)$. The chemopreventive effects 
of curcumin towards tumorigenesis have been observed in both the initiation and the post-initiation phases (194). The turmeric spice curcumin has been reported to exhibit pleiotropic inhibitory actions towards carcinogenesis on a plethora of signalling pathways in various animal models at multiple organ sites especially the prostate $(195,196)$.

The key mechanisms underlying the anti-carcinogenic action of curcumin in both androgen-dependent and androgenindependent prostate cancer cells include i) down-regulation of inhibitor of DNA binding 1 by small interfering RNA, ii) restoration of tumour suppressor p53, iii) activation of Nrf2 signalling, iv) down-regulation of VEGF expression, v) modulation of toll-like receptors (TLR)/interleukin-1 receptor (IL-1R) pathway, vi) transformation of growth factor beta1 (TGF- $\beta 1)$, vii) modulation of inflammatory mediators such as inducible nitric oxide synthase (iNOS) and cyclooxygenase-2 (COX2), ix) promotion of apoptosis by down-regulating Bcl2 and up-regulating Bax and $\mathrm{x}$ ) suppression of MMP9 (197202). Pro-inflammatory mediators such as (iNOS) and (COX2) have been suggested to promote carcinogenesis as aberrant expression of (COX2) was reported in both premalignant and malignant human tumours including prostate cancer $(160,161)$. Matrix metalloproteinases (MMPs) are implicated in tumour angiogenesis, metastasis and invasion (203). Further, curcumin has been reported to modulate NFkB, PI3K/Akt/mTOR, MAPK, JAK/STAT signalling, inhibit ROS production and CXC chemokine receptor 4 (CXCR4) and interleukin-6 (IL-6) receptor expression in prostate cancer cells via MAOA/mTOR/HIF-1 $\alpha$ signalling and inhibition of cancer-associated fibroblast-driven prostate cancer invasion $(117,204)$. Cancer-associated fibroblasts are crucial determinants of tumorigenesis, progression and metastasis of cancer. Additionally, curcumin has been reported to modify the chromatin landscape by supressing histone acetylation, coactivator protein $\mathrm{p} 300$, and element-binding protein occupancy at sites of androgen receptor function responsible for hormone therapy failures and aggressive phenotypes of prostate cancer (205).

While studies with curcumin have provided evidence regarding its tolerability and nontoxicity (206), the above molecular and preclinical success of curcumin in prostate cancer has not been reproduced in clinical trials. However, curcumin has still received much attention in prostate cancer chemoprevention because of its evidenced anti-inflammatory and antioxidant properties as well as robust evidence from in vitro and in vivo studies demonstrating its diverse anticarcinogenic effects against prostate cancer in cell lines and animal models.

Meta-analyses of randomised controlled trials, which assessed the effect of curcumin-containing supplements on oxidative stress and inflammation biomarkers, have suggested that curcumin-containing supplements exert antioxidant and anti-inflammatory effects through significant reductions in circulating serum concentrations of a panel of mediators such as malondialdehyde, interleukin 6 (IL-6) and TNF- $\alpha$ (207-210). While interleukin-6 is a multi-functional cytokine that plays a key role in carcinogenesis of many human cancers, TNF- $\alpha$ is one of the major molecular mediators of a wide range of chronic inflammation and inflammation-related disorders (211). There is increasing evidence from numerous molecular pathology, histopathological and epidemiological studies that chronic oxidation and inflammation in prostate plays a key role in the aetiology of its carcinogenesis $(212,213)$.

To evaluate the potential effects of curcumin as a prostate cancer preventive agent, a randomised double-blind placebocontrolled clinical trial involving 85 participants who had prostate biopsies but had neither prostatic intraepithelial neoplasia nor prostate cancer was undertaken. After six months of daily intake of curcumin in combination with isoflavones, the combination was found to significantly reduce PSA serum levels in the of participants who had a serum PSA level $\geq 10 \mu \mathrm{g} / \mathrm{ml}$ and supress androgen receptor expression in the supplement-treated group compared with that of the placebo (214). Moreover, supplementation of $3 \mathrm{~g}$ per day of curcumin for 3 months has been reported to increase plasma total antioxidant capacity significantly among 40 patients treated with radiotherapy for prostate cancer $(p<0.001)(215)$. A prospective randomised phase III trial (ClinicalTrials.gov Identifier: NCT02064673) is on-going now to compare the effect of adjuvant supplementation of curcumin $500 \mathrm{mg}$ twice a day for 6 months on recurrence-free survival as compared to placebo in the treatment of 600 prostate cancer patients after radical prostatectomy (216).

The first and foremost challenge to achieve desirable anticarcinogenic effects of curcumin remains its bioavailability, which cannot be overcome just by increasing the frequency of administration or the administered dose (217). To improve the bioavailability of curcumin, a combinatorial approach to obtain potentially synergistic or additive chemopreventive response can be used. A recent meta-analyses of randomised controlled trials has reported that the antioxidant activities were greater when curcumin was concomitantly taken with piperine compared with curcumin alone (208). Piperine does not only enhance the chemoprevention outcome of curcumin, but has been reported to significantly increase the absorption, serum concentration and bioavailability of curcumin in humans up to 20 -fold when they are concomitantly administered $(218,219)$.

Piperine is a major bioactive alkaloid that is present in the black pepper at $5 \%$ to $9 \%$. It has been shown that piperine exerts preventive and even therapeutic effects on both androgen-dependent and androgen-independent prostate cancers. A recent review on preclinical studies has demonstrated its selective cytotoxic properties on cancerous cells compared to normal cells (220). In human prostate cancer cells and animal models xeno-transplanted with prostate cancer 
cells, piperine has been reported to promote autophagy, induce cell cycle arrest at $\mathrm{G}_{0} / \mathrm{G}_{1}$ via down-regulation of cyclin $\mathrm{D} 1$ and cyclin A and up-regulation of p21 and p27, trigger apoptosis and inhibit the growth and proliferation of both androgensensitive and androgen-insensitive prostate tumours in dosedependent manner $(221,222)$. Piperine has also been shown to inhibit expression of nuclear factor-kB (NF-kB) transcription factor and down-regulate phosphorylated STAT-3 (221). Additionally, in a xenograft models of human castrationresistant prostate cancer, piperine and docetaxel in combination have been reported to remarkably enhance the anti-tumour effectiveness of docetaxel (223).

\section{Zinc}

Zinc plays a key role in the physiological function and regulation of prostate cell growth. Zinc dysregulation and imbalance of zinc transporters have been reported in numerous cancers including prostate cancer $(224,225)$. Alterations in Intracellular and serum zinc (II) levels as a result of imbalance of zinc transporters in prostate cancer patients has been previously delineated (226). While zinc is available at a very high concentration in healthy prostate tissues, it significantly diminishes in the course of prostate carcinogenesis and its intracellular level has been reported to be inversely correlated with prostate cancer progression (227). It has been noted that the level of zinc in prostate tissue declines early preceding histopathological alterations and continues to diminish throughout the progression phase toward castration-resistant disease (228-230). High tissue Zinc concentrations have been found to inhibit the conversion of testosterone to dihydrotestosterone (DHT). The latter is considered the preferred ligand of androgen receptor which plays a central role for growth regulation in benign hyperplasia, androgenstimulated and castration-recurrent prostate cancers in all stages of the disease, even after pharmacological or surgical androgen deprivation (231). There is now strong evidence from animal and laboratory experimental studies suggesting that zinc has a protective effect on prostate cancer, albeit at high doses, and that loss of capability to amass high levels of zinc is a crucial factor in the development and progression of prostate cancer.

Zinc has been reported to induce cell-cycle arrest and apoptosis by acting on numerous molecular regulators of apoptotic cell death such as caspases and proteins from the $\mathrm{Bcl}$ and Bax families leading to inhibition of human prostatic carcinoma cell growth (232)

A recent systematic review and meta-analysis of fourteen studies (731 cases and 574 controls) has reported that zinc concentrations in prostatic fluid and seminal plasma from chronic prostatitis patients were significantly lower than normal controls [SMD (95\%CI) -246.71 (-347.97, -145.44), -20.74 $(-35.11,-6.37)$ respectively] (233). Another systematic review and meta-analysis of fourteen studies (1318 cases and 1413 controls) has shown that serum zinc concentrations in prostate cancer patients were statistically significantly lower than that of benign prostatic hyperplasia patients and normal controls (standard mean differences of the serum zinc concentrations: SMD $(95 \% \mathrm{CI})=-0.94[-1.57,-0.32] ;-1.18[-1.90,-0.45]$, respectively (234). In line with the above meta-analyses, a meta-analysis of 114 cross-sectional, cohort and case control studies involving 22,737 participants has illustrated that decreased serum zinc levels were associated with most cancers including prostate cancer (prostate serum (effect size $=-1.36$; $95 \% \mathrm{CI}=-1.97$ to -0.75$)$, Heterogeneity $I^{2}=97.93$ ) (235).

Although it has been hypothesised that prostate cancer risk may be reduced by zinc intake both from supplements and/or diet, a prospective cohort study involving 35,242 men has reported a significant inverse trend between 10-yr long-term supplemental zinc intake but not dietary zinc, and the risk of clinically-relevant advanced disease (regionally invasive or distant metastatic prostate cancer) $(\mathrm{HR}=0.34(95 \% \mathrm{CI}=0.13-$ 1.09 ) for greater than $15 \mathrm{mg} /$ day versus no use, $\mathrm{p}$ for trend 0.04) (236).

\section{Limitations}

This review represents an account of the latest and most robust available findings on naturally available micronutrients and phytochemicals that have been studied in chemoprevention of prostate cancer. Although generally considered as safe, several challenges exist in the translational development of chemopreventive dietary factors such as the lack of instantaneous effects and concerns over unexpected doselimiting toxicities when long-term high-dose supplementation is used in primary chemoprevention to overcome low serum bioavailability and/or low target-organ. Furthermore, the variable and occasionally inconsistent findings along with scarcity of well-designed randomised controlled trials involving standardised formulations, dosages, dosing periods and larger sample sizes suggest that these results should be interpreted with some caution. The currently available randomised controlled trials have all involved different trial durations, treatment periods and dissimilar doses of micronutrients and phytochemicals. Regarding the epidemiological and observational correlation studies, there are concerns related to the precision of self-administered questionnaires and in-person interviews in evaluating dietary intake. There are also issues related to confounding genetically associated factors, lifestyle related influences, recall bias and variance in recall periods (ranging from prior to diagnosis or prior to onset of symptoms or before diagnosis). Dissimilar types and stages of prostate cancer were also evaluated in different studies; While several studies did not even provide information on the stage or type of prostate cancer, others either involved patients with high-grade prostatic 
intraepithelial neoplasia or focused on patients with atypical small acinar proliferation prostate disease.

To measure the effect of specific dietary agents against prostate cancer and allow a "personalised medicine" approach, well-designed clinical trials with rigorous methodological interpretations to define individuals who respond and those who do not respond to dietary interventions are required. A randomised large-scale phase III clinical trial (MEAL study) is currently underway to provide robust evidence regarding the efficacy of increased vegetable consumption to prevent progression in prostate cancer patients; 478 patients with clinically localised prostate cancer on active surveillance from 91 study sites were randomised to either a vegetable-intense dietary pattern group or a control dietary group $(237,238)$.

In view of the evidence of reduced bioavailability and highly plasma concentration variability of these micronutrients, reported in some clinical studies, supplementation or consumption of the pure compound extracts seems to be more promising. Nevertheless, to prevent potential drug interactions, instructions and guidelines should be drawn up regarding the administration schedule of these dietary agents. The limitations, as illustrated above, regarding the epidemiological and observational correlation studies and scarcity of well-designed randomised controlled trials are largely circumvented by several lines of evidence from in vitro and animal studies as well as evidence based on high quality epidemiological and clinical studies included in this review. Such studies proved invaluable in identifying and examining potential anticarcinogens.

\section{Conclusion and Future Perspectives}

With increasing life expectancy and the adoption of lifestyles, such as poor diet, that are considered to increase prostate cancer risk, the projected future prostate cancer burden is expected to be unquestionably relatively higher, particularly in countries with rapid economic and societal transition (239). As nutritional factors are modifiable with no significant doselimiting toxicities, identifying plant-based micronutrients and dietary components that modulate prostate cancer risk and aggressiveness holds the potential for effective yet practical strategies for primary chemoprevention settings.

Cumulative and well-documented molecular, preclinical and sufficient clinical evidence demonstrates that certain micronutrients (namely Lycopene, Epigallocatechin gallate, Sulforaphane, Indole-3-Carbinol, Resveratrol, Quercetin, Curcumin \& Piperine) and Zinc display multiple antitumoural and anticarcinogenic effects against prostate cancer. These effects are exerted via inhibition of proliferation, invasion, angiogenesis and metastasis. In addition to their antioxidant properties, the antitumorigenic and anticarcinogenic activities displayed by these phytochemicals against prostate cancer are mainly related to inducing cell cycle arrest, triggering apoptotic cell death, regulating oncogenic signalling pathways and hormone receptors including androgen receptor. As prostate cancer heterogeneity represents a challenge for clinical interventions where different survival oncogenic signalling pathways are activated, the utility of a combinatorial approach of these micronutrients with their multi-targeted 'pleiotropic' effects offers a real advantage for chemoprevention of prostate cancer and its recurrence and as an integrated part of standard prostate cancer therapy. Combining the identified dietary compounds, with or without concurrent treatment, is strongly suggested from emerging evidence in prostate cancer. Because there is little or no progress in the transition of these micronutrients to bedside as first line chemoprevention it is inevitable to rely upon the available animal, pre-clinical and epidemiological studies. Using the safest formulation and most effective dosage for prostate cancer chemoprevention, it would be prudent for men at increased risk of prostate cancer to consider using dietary sources or supplements that encompass these micronutrients.

\section{Conflicts of Interest}

The Authors declare that they have no competing interests regarding this study.

\section{Authors' Contributions}

Kinan Mokbel conceived the topic of the article and performed the literature review. Kefah Mokbel supervised the study and drafted the manuscript. Umar Wazir proof-read and critiqued the manuscript and drafted revisions. All Authors read and approved the final manuscript.

\section{Acknowledgements}

This study was funded by grants from the Breast Cancer Hope Foundation (London, UK).

\section{References}

1 Plummer M, de Martel C, Vignat J, Ferlay J, Bray F and Franceschi S: Global burden of cancers attributable to infections in 2012: a synthetic analysis. Lancet Glob Heal 4(9): e609-e616, 2016. PMID: 27470177. DOI: 10.1016/S2214-109X(16)30143-7

2 World Health Organization: fact-sheets/detail/cancer. Fact sheet, 2018. Available from: https://www.who.int/news-room/factsheets/detail/cancer [last accessed August 20, 2019].

3 Prostate cancer I World Cancer Research Fund International. Available from: https://www.wcrf.org/dietandcancer/prostatecancer [last accessed May 23, 2019]

4 Bray F, Ferlay J, Soerjomataram I, Siegel RL, Torre LA and Jemal A: Global cancer statistics 2018: GLOBOCAN estimates of incidence and mortality worldwide for 36 cancers in 185 countries. CA Cancer J Clin 68(6): 394-424, 2018. PMID: 30207593. DOI: $10.3322 /$ caac. 21492

5 Prostate cancer statistics I Cancer Research UK. Available from: https://www.cancerresearchuk.org/health-professional/cancerstatistics/statistics-by-cancer-type/prostate-cancer [last accessed May 23, 2019] 
6 Morgan SC, Hoffman K, Loblaw DA, Buyyounouski MK, Patton C, Barocas D, Bentzen S, Chang M, Efstathiou J, Greany P, Halvorsen P, Koontz BF, Lawton C, Leyrer CM, Lin D, Ray M and Sandler H: Prostate Cancer: types of treatment. J Clin Oncol 36(34): 3411-3430, 2018. PMID: 30307776. DOI: 10.1200/JCO. 18.01097

7 El-Amm J and Aragon-Ching JB: The current landscape of treatment in non-metastatic castration-resistant prostate cancer. Clin Med Insights Oncol 13: 117955491983392, 2019. PMID: 30872920. DOI: $10.1177 / 1179554919833927$

8 Chen FZ and Zhao XK: Prostate cancer: current treatment and prevention strategies. Iran Red Crescent Med J 15(4): 279-284, 2013. PMID: 24082997. DOI: 10.5812/ircmj.6499

9 Komura K, Sweeney CJ, Inamoto T, Ibuki N, Azuma H and Kantoff PW: Current treatment strategies for advanced prostate cancer. Int J Urol 25(3): 220-231, 2018. PMID: 29266472. DOI: 10.1111/iju.13512

10 Ferraldeschi R, Pezaro C, Karavasilis V and de Bono J: Abiraterone and novel antiandrogens: overcoming castration resistance in prostate cancer. Annu Rev Med 64(1): 1-13, 2013. PMID: 23020876. DOI: 10.1146/annurev-med-121211091605

11 Roudier MP, True LD, Higano CS, Vesselle H, Ellis W, Lange P and Vessella RL: Phenotypic heterogeneity of end-stage prostate carcinoma metastatic to bone. Hum Pathol 34(7): 646-653, 2003. PMID: 12874759. DOI: 10.1016/S0046-8177(03)00190-4

12 Pagliarulo V: Androgen deprivation therapy for prostate cancer. In: Advances in Experimental Medicine and Biology. Springer, Cham, pp. 1-30, 2018. PMID: 30324345. DOI: 10.1007/978-3319-99286-0_1

13 Pelekanou V and Castanas E: Androgen control in prostate cancer. J Cell Biochem 117(10): 2224-2234, 2016. PMID: 27104784. DOI: $10.1002 /$ jcb. 25572

14 Morgentaler A and Traish AM: Shifting the paradigm of testosterone and prostate cancer: The saturation model and the limits of androgen-dependent growth. Eur Urol 55(2): 310-321, 2009. PMID: 18838208. DOI: 10.1016/J.EURURO 2008.09.024.

15 Ranieri G, Vacca A, Ranieri G, Gnoni A and Dammacco F: Novel strategies in the treatment of castration-resistant prostate cancer (Review). Int J Oncol 40(5): 1313-1320, 2012. PMID: 22322981. DOI: 10.3892/ijo.2012.1364

16 Tilki D, Schaeffer EM and Evans CP: Understanding mechanisms of resistance in metastatic castration-resistant prostate cancer: The role of the androgen receptor. Eur Urol Focus 2(5): 499-505, 2016. PMID: 28723515. DOI: 10.1016/J.EUF.2016.11.013

17 Watson PA, Arora VK and Sawyers CL: Emerging mechanisms of resistance to androgen receptor inhibitors in prostate cancer. Nat Rev Cancer 15(12): 701-711, 2015. PMID: 26563462. DOI: $10.1038 / \mathrm{nrc} 4016$.

18 Scher HI, Fizazi K, Saad F, Taplin M-E, Sternberg CN, Miller K, de Wit R, Mulders P, Chi KN, Shore ND, Armstrong AJ, Flaig TW, Fléchon A, Mainwaring P, Fleming M, Hainsworth JD, Hirmand M, Selby B, Seely L and de Bono JS: Increased survival with enzalutamide in prostate cancer after chemotherapy. N Engl J Med 367(13): 1187-1197, 2012. PMID: 22894553. DOI: $10.1056 /$ NEJMoa1207506

19 Van Poppel H and Tombal B: Chemoprevention of prostate cancer with nutrients and supplements. Cancer Manag Res 3: 91100, 2011. PMID: 21629831. DOI: 10.2147/CMR.S18503
20 Shoag J and Barbieri CE: Clinical variability and molecular heterogeneity in prostate cancer. Asian J Androl 18(4): 543-548, 2016. PMID: 27080479. DOI: 10.4103/1008-682X.178852

21 FDA. PROPECIA $\AA$ - Finasteride. Available from: https://www.accessdata.fda.gov/drugsatfda_docs/label/2011/0207 88s018lbl.pdf [last accessed August 20, 2019]

22 FDA. AVODART - Dutasteride. Available from: https://www.accessdata.fda.gov/drugsatfda_docs/label/2011/0213 19s023s025lbl.pdf [last accessed August 20, 2019]

23 Hamilton RJ, Kahwati LC and Kinsinger LS: Knowledge and Use of Finasteride for the Prevention of Prostate Cancer. Cancer Epidemiol Biomarkers Prev 19(9): 2164-2171, 2010. PMID: 20699373. DOI: 10.1158/1055-9965.EPI-10-0082

24 Syed DN, Khan N, Afaq F and Mukhtar H: Chemoprevention of prostate cancer through dietary agents: Progress and promise. Cancer Epidemiol Prev Biomarkers 16(11): 2193-2203, 2007. PMID: 18006906. DOI: 10.1158/1055-9965.EPI-06-0942

25 Koochekpour S, Buckles E, Shourideh M, Hu S, Chandra D, Zabaleta $\mathrm{J}$ and Attwood K: Androgen receptor mutations and polymorphisms in African American prostate cancer. Int J Biol Sci 10(6): 643-651, 2014. PMID: 24948877. DOI: 10.7150/ijbs.8974

26 Diet, Nutrition, Physical Activity and Cancer: a Global Perspective. Available from: https://www.wcrf.org/dietandcancer [last accessed May 22, 2019]

27 Nelson WG, De Marzo AM and Isaacs WB: Prostate Cancer. N Engl J Med 349(4): 366-381, 2003. PMID: 12878745. DOI: 10.1056/NEJMra021562

28 Center MM, Jemal A, Lortet-Tieulent J, Ward E, Ferlay J, Brawley $\mathrm{O}$ and Bray $\mathrm{F}$ : International variation in prostate cancer incidence and mortality rates. Eur Urol 61(6): 1079-1092, 2012. PMID: 22424666. DOI: 10.1016/j.eururo.2012.02.054

29 Marks LSS, Kojima M, Demarzo A, Heber D, Bostwick DGG, Qian J, Dorey FJJ, Veltri RWW, Mohler JLL and Partin AWW: Prostate cancer in native Japanese and Japanese-American men: Effects of dietary differences on prostatic tissue. Urology 64(4): 765-771, 2004. PMID: 15491717. DOI: 10.1016/j.urology.2004. 05.047

30 Shimizu H, Ross R, Bernstein L, Yatani R, Henderson B and Mack T: Cancers of the prostate and breast among Japanese and white immigrants in Los Angeles County. Br J Cancer 63(6): 963-966, 1991. PMID: 2069852. DOI: 10.1038/bjc. 1991.210 .

31 Kurahashi N, Sasazuki S, Iwasaki M and Inoue M: Green tea consumption and prostate cancer risk in Japanese men: A prospective study. Am J Epidemiol 167(1): 71-77, 2007. PMID: 17906295. DOI: $10.1093 /$ aje/kwm249

32 Jain R V, Mills PK and Parikh-Patel A: Cancer incidence in the south Asian population of California, 1988-2000. J Carcinog 4: 21, 2005. PMID: 16283945. DOI: 10.1186/1477-3163-4-21

33 Namiki M, Akaza H, Lee SE, Song J-M, Umbas R, Zhou L, Cheok Lee B, Cheng C, Chung MK, Fukagai T, Hinotsu S and Horie S: Prostate Cancer Working Group Report. Jpn J Clin Oncol 40(1): i70-i75, 2010. PMID: 20870924. DOI: 10.1093/jjco/hyq130

34 Baade PD, Youlden DR and Krnjacki LJ: International epidemiology of prostate cancer: Geographical distribution and secular trends. Mol Nutr Food Res 53(2): 171-184, 2009. PMID: 19101947. DOI: 10.1002/mnfr.200700511

35 Ito K: Prostate cancer in Asian men. Nat Rev Urol 11(4): 197212, 2014. PMID: 24595118. DOI: 10.1038/nrurol.2014.42 
36 Hori S, Butler E and McLoughlin J: Prostate cancer and diet: food for thought? BJU Int 107(9): 1348-1359, 2011. PMID: 21518228. DOI: 10.1111/j.1464-410X.2010.09897.x

37 Ma RW-L and Chapman K: A systematic review of the effect of diet in prostate cancer prevention and treatment. J Hum Nutr Diet 22(3): 187-199, 2009. PMID: 19344379. DOI: 10.1111/j.1365277X.2009.00946.x

38 Yedjou CG, Tchounwou PB, Payton M, Miele L, Fonseca DD, Lowe L and Alo RA: Assessing the racial and ethnic disparities in breast cancer mortality in the United States. Int J Environ Res Public Health 14(5), 2017. PMID: 28475137. DOI: 10.3390/ ijerph 14050486

39 Walker M, Aronson KJ, King W, Wilson JWL, Fan W, Heaton JPW, MacNeily A, Nickel JC and Morales A: Dietary patterns and risk of prostate cancer in Ontario, Canada. Int $\mathrm{J}$ Cancer 116(4): 592-598, 2005. PMID: 15825170. DOI: 10.1002/ ijc. 21112

40 Ambrosini GL, Fritschi L, de Klerk NH, Mackerras D and Leavy $\mathrm{J}$ : Dietary patterns identified using factor analysis and prostate cancer risk: A case control study in Western Australia. Ann Epidemiol 18(5): 364-370, 2008. PMID: 18261927. DOI: 10.1016/J.ANNEPIDEM.2007.11.010

41 De Stefani E, Ronco AL, Deneo-Pellegrini H, Boffetta P, Aune D, Acosta G, Brennan P, Ferro G and Mendilaharsu M: Dietary patterns and risk of advanced prostate cancer: a principal component analysis in Uruguay. Cancer Causes Control 21(7): 1009-1016, 2010. PMID: 20198507. DOI: 10.1007/s10552-0109527-4

42 Yang M, Kenfield SA, Van Blarigan EL, Batista JL, Sesso HD, Ma J, Stampfer MJ and Chavarro JE: Dietary patterns after prostate cancer diagnosis in relation to disease-specific and total mortality. Cancer Prev Res 8(6): 545-551, 2015. PMID: 26031631. DOI: 10.1158/1940-6207.CAPR-14-0442

43 Bray F, Lortet-Tieulent J, Ferlay J and Forman D: Prostate cancer incidence and mortality trends in 37 European countries: An overview. Eur J Cancer 46(17): 3040-3052, 2010. PMID: 21047585. DOI: 10.1016/J.EJCA.2010.09.013

44 Itsiopoulos C, Hodge A and Kaimakamis M: Can the Mediterranean diet prevent prostate cancer? Mol Nutr Food Res 53(2): 227-239, 2009. PMID: 19051189. DOI: 10.1002/mnfr. 200800207

45 Sofi F, Abbate R, Gensini GF and Casini A: Accruing evidence on benefits of adherence to the Mediterranean diet on health: an updated systematic review and meta-analysis. Am J Clin Nutr 92(5): 1189-1196, 2010. PMID: 20810976. DOI: 10.3945/ajen.2010.29673

46 Schwingshackl L and Hoffmann G: Adherence to Mediterranean diet and risk of cancer: An updated systematic review and metaanalysis of observational studies. Cancer Med 4(12): 1933-1947, 2015. PMID: 26471010. DOI: $10.1002 /$ cam 4.539

47 Kenfield SA, DuPre N, Richman EL, Stampfer MJ, Chan JM and Giovannucci EL: Mediterranean diet and prostate cancer risk and mortality in the health professionals follow-up study. Eur Urol 65(5): 887-894, 2014. PMID: 23962747. DOI: 10.1016/ J.EURURO.2013.08.009

48 Möller E, Galeone C, Andersson TM-L, Bellocco R, Adami H$\mathrm{O}$, Andrén O, Grönberg H, La Vecchia C, Mucci LA and Bälter $\mathrm{K}$ : Mediterranean Diet Score and prostate cancer risk in a Swedish population-based case-control study. J Nutr Sci 2: e15, 2013. PMID: 25191563. DOI: 10.1017/jns.2013.2
49 Ostan R, Béné MC, Spazzafumo L, Pinto A, Donini LM, Pryen F, Charrouf Z, Valentini L, Lochs H, Bourdel-Marchasson I, Blanc-Bisson C, Buccolini F, Brigidi P, Franceschi C and d'Alessio PA: Impact of diet and nutraceutical supplementation on inflammation in elderly people. Results from the RISTOMED study, an open-label randomized control trial. Clin Nutr 35(4): 812-818, 2016. PMID: 26249791. DOI: 10.1016/J.CLNU.2015. 06.010

50 Oomen D, Lemmens V, Oenema A, Benetou V, Trichopoulou A, Coebergh JW, Barendregt $\mathrm{J}$ and de Vries E: Increased consumption of fruit and vegetables and future cancer incidence in selected European countries. Eur J Cancer 46(14): 2563-2580, 2010. PMID: 20843486. DOI: 10.1016/J.EJCA.2010.07.026

51 Turati F, Rossi M, Pelucchi C, Levi F and La Vecchia C: Fruit and vegetables and cancer risk: a review of southern European studies. Br J Nutr 113(S2): S102-S110, 2015. PMID: 26148912. DOI: $10.1017 / \mathrm{S} 0007114515000148$

52 Pascual-Geler M, Urquiza-Salvat N, Cozar JMM, RoblesFernandez I, Rivas A, Martinez-Gonzalez LJJ, Ocaña-Peinado FMM, Lorente JAA and Alvarez-Cubero MJJ: The influence of nutritional factors on prostate cancer incidence and aggressiveness. 21(1): 31-39, 2018. PMID: 28929838. DOI: $10.1080 / 13685538.2017 .1379491$

53 Tantamango-Bartley Y, Knutsen SF, Knutsen R, Jacobsen BK, Fan J, Beeson WL, Sabate J, Hadley D, Jaceldo-Siegl K, Penniecook J, Herring P, Butler T, Bennett H and Fraser G: Are strict vegetarians protected against prostate cancer? Am J Clin Nutr 103(1): 153-160, 2016. PMID: 26561618. DOI: 10.3945/ajcn.114.106450

54 Vance TM, Wang Y, Su LJ, Fontham ETH, Steck SE, Arab L, Bensen JT, Mohler JL, Chen M-H and Chun OK: Dietary total antioxidant capacity is inversely associated with prostate cancer aggressiveness in a population-based study. Nutr Cancer 68(2): 214-224, 2016. PMID: 26847416. DOI: 10.1080/01635581.2016. 1134596

55 Canby-Hagino ED and Thompson IM: Mechanisms of Disease: prostate cancer - a model for cancer chemoprevention in clinical practice. Nat Clin Pract Oncol 2(5): 255-261, 2005. PMID: 16264961. DOI: $10.1038 /$ ncponc0172

56 Sonn GA, Aronson W and Litwin MS: Impact of diet on prostate cancer: a review. Prostate Cancer Prostatic Dis 8(4): 304-310, 2005. PMID: 16130015. DOI: 10.1038/sj.pcan.4500825

57 Lall R, Syed D, Adhami V, Khan M, Mukhtar H, Lall RK, Syed DN, Adhami VM, Khan MI and Mukhtar H: Dietary polyphenols in prevention and treatment of prostate cancer. Int J Mol Sci 16(2): 3350-3376, 2015. PMID: 25654230. DOI: 10.3390/ijms 16023350

58 Prodanov M, Sierra I and Vidal-Valverde C: Influence of soaking and cooking on the thiamin, riboflavin and niacin contents of legumes. Food Chem 84(2): 271-277, 2004. DOI: 10.1016/S0308-8146(03)00211-5

59 Bongoni R, Verkerk R, Steenbekkers B, Dekker M and Stieger M: Evaluation of Different Cooking Conditions on Broccoli (Brassica oleracea var. italica) to Improve the Nutritional Value and Consumer Acceptance. Plant Foods Hum Nutr 69(3): 228234, 2014. PMID: 24853375. DOI: 10.1007/s11130-014-0420-2

60 USDA Table of Nutrient Retention Factors, Release 6 (2007) I National Agricultural Library, 2007. Available from: https://data.nal.usda.gov/dataset/usda-table-nutrient-retentionfactors-release-6-2007 
61 Neff MR, Bhavsar SP, Braekevelt E and Arts MT: Effects of different cooking methods on fatty acid profiles in four freshwater fishes from the Laurentian Great Lakes region. Food Chem 164: 544-550, 2014. PMID: 24996368. DOI: 10.1016/ j.foodchem.2014.04.104

62 Sala-Vila A and Calder PC: Update on the Relationship of Fish Intake with Prostate, Breast, and Colorectal Cancers. Crit Rev Food Sci Nutr 51(9): 855-871, 2011. PMID: 21888535. DOI: 10.1080/10408398.2010.483527

63 Cancer Prevention Recommendations I World Cancer Research Fund International., 2016. Available from: http://www. wcrf.org/int/research-we-fund/our-cancer-preventionrecommendations

64 Nevedomskaya E, Baumgart SJ and Haendler B: Recent Advances in Prostate Cancer Treatment and Drug Discovery. Int J Mol Sci 19(5), 2018. PMID: 29734647. DOI: 10.3390/ijms19051359

65 Jian L, Lee AH and Binns CW: Tea and lycopene protect against prostate cancer. Asia Pac J Clin Nutr 16: 453-457, 2007. PMID: 17392149.

66 Block KI, Koch AC, Mead MN, Tothy PK, Newman RA and Gyllenhaal C: Impact of antioxidant supplementation on chemotherapeutic efficacy: A systematic review of the evidence from randomized controlled trials. Cancer Treat Rev 33(5): 407-418, 2007. PMID: 17367938. DOI: 10.1016/j.ctrv. 2007.01.005

67 Gröber U, Kisters K and Adamietz IA: Vitamin D in oncology: Update 2015. Med Monatsschr Pharm 38(12): 512-516, 2015. PMID: 26837159.

68 Nechuta S, Lu W, Chen Z, Zheng Y, Gu K, Cai H, Zheng W and Shu XO: Vitamin supplement use during breast cancer treatment and survival: a prospective cohort study. Cancer Epidemiol Biomarkers Prev 20(2): 262-271, 2011. PMID: 21177425. DOI: 10.1158/1055-9965.EPI-10-1072

69 Block KI, Koch AC, Mead MN, Tothy PK, Newman RA and Gyllenhaal C: Impact of antioxidant supplementation on chemotherapeutic toxicity: A systematic review of the evidence from randomized controlled trials. Int $\mathrm{J}$ Cancer 123(6): 1227-1239, 2008. PMID: 18623084. DOI: 10.1002/ ijc. 23754 .

70 Gröber U, Holzhauer P, Kisters K, Holick MF and Adamietz IA: Micronutrients in Oncological Intervention. Nutrients 8(3), 2016. PMID: 26985904. DOI: 10.3390/NU8030163

71 Mohanty NK, Saxena S, Singh UP, Goyal NK and Arora RP: Lycopene as a chemopreventive agent in the treatment of highgrade prostate intraepithelial neoplasia. Urol Oncol Semin Orig Investig 23(6): 383-385, 2005. DOI: 10.1016/J.UROLONC. 2005.05.012

72 Bunker $\mathrm{CH}$, McDonald AC, Evans RW, de la Rosa N, Boumosleh JM and Patrick AL: A randomized trial of lycopene supplementation in tobago men with high prostate cancer risk. Nutr Cancer 57(2): 130-137, 2007. PMID: 17571945. DOI: $10.1080 / 01635580701274046$

73 Mangels AR, Holden JM, Beecher GR, Forman MR and Lanza E: Carotenoid content of fruits and vegetables: An evaluation of analytic data. J Am Diet Assoc 93(3): 284-296, 1993. PMID: 8440826. DOI: 10.1016/0002-8223(93)91553-3

74 Di Mascio P, Kaiser S and Sies H: Lycopene as the most efficient biological carotenoid singlet oxygen quencher. Arch Biochem Biophys 274(2): 532-538, 1989. PMID: 2802626. DOI: 10.1016/ 0003-9861(89)90467-0
75 Conn PF, Schalch W and Truscott TG: The singlet oxygen and carotenoid interaction. J Photochem Photobiol B 11(1): 41-47, 1991. PMID: 1791493. DOI: 10.1016/1011-1344(91)80266-K

76 Matsushima-Nishiwaki R, Shidoji Y, Nishiwaki S, Yamada T, Moriwaki $\mathrm{H}$ and Muto Y: Suppression by carotenoids of microcystin-induced morphological changes in mouse hepatocytes. Lipids 30(11): 1029-1034, 1995. PMID: 8569431.

77 Pool-Zobel B, Bub A, Müller H, Wollowski I and Rechkemmer G: Consumption of vegetables reduces genetic damage in humans: first results of a human intervention trial with carotenoid-rich foods. Carcinogenesis 18(9): 1847-1850, 1997. PMID: 9328185. DOI: 10.1093/carcin/18.9.1847

78 Rao AV and Agarwal S: Role of lycopene as antioxidant carotenoid in the prevention of chronic diseases: A review. Nutr Res 19(2): 305-323, 1999. PMID: 11022869.

79 Rafi MM, Kanakasabai S, Reyes MD and Bright JJ: Lycopene modulates growth and survival associated genes in prostate cancer. J Nutr Biochem 24(10): 1724-1734, 2013. PMID: 23746934. DOI: 10.1016/J.JNUTBIO.2013.03.001

80 Yang C-M, Lu Y-L, Chen H-Y and Hu M-L: Lycopene and the LXR $\alpha$ agonist T0901317 synergistically inhibit the proliferation of androgen-independent prostate cancer cells via the PPAR $\gamma$ LXR $\alpha$-ABCA1 pathway. J Nutr Biochem 23(9): 1155-1162, 2012. PMID: 22137263. DOI: 10.1016/J.JNUTBIO.2011.06.009.

81 Giovannucci E, Rimm EB, Liu Y, Stampfer MJ and Willett WC: A prospective study of tomato products, lycopene, and prostate cancer risk. CancerSpectrum Knowl Environ 94(5): 391-398, 2002. PMID: 11880478. DOI: 10.1093/jnci/94.5.391

82 Er V, Lane JA, Martin RM, Emmett P, Gilbert R, Avery KNL, Walsh E, Donovan JL, Neal DE, Hamdy FC and Jeffreys M: Adherence to dietary and lifestyle recommendations and prostate cancer risk in the prostate testing for cancer and treatment (ProtecT) trial. Cancer Epidemiol Biomarkers Prev 23(10): 20662077, 2014. PMID: 25017249. DOI: 10.1158/1055-9965.EPI-140322

83 Cataño JG, Trujillo CG, Caicedo JI, Bravo-Balado A, Robledo D, Mariño-Alvarez AM, Pedraza A, Arcila MJ and Plata M: Efficacy of lycopene intake in primary prevention of prostate cancer: a systematic review of the literature and meta-analysis. Arch Esp Urol 71(2): 187-197, 2018. PMID: 29521265.

84 Rowles JLL, Ranard KMM, Applegate CCC, Jeon S, An R and Erdman JWW: Processed and raw tomato consumption and risk of prostate cancer: a systematic review and dose-response metaanalysis. Prostate Cancer Prostatic Dis 21(3): 319-336, 2018. PMID: 29317772. DOI: 10.1038/s41391-017-0005-x

85 CHEN J, Song Y and ZHANG L: Lycopene/tomato consumption and the risk of prostate cancer: a systematic review and metaanalysis of prospective studies. J Nutr Sci Vitaminol (Tokyo) 59(3): 213-223, 2013. PMID: 23883692. DOI: 10.3177/ jnsv. 59.213

86 Etminan M, Takkouche B and Caamaño-Isorna F: The role of tomato products and lycopene in the prevention of prostate cancer: a meta-analysis of observational studies. Cancer Epidemiol Biomarkers Prev 13(3): 340-345, 2004. PMID: 15006906.

87 Key TJJ, Appleby PNN, Travis RCC, Albanes D, Alberg AJJ, Barricarte A, Black A, Boeing H, Bueno-De-Mesquita HBB, Chan JMM, Chen C, Cook MBB, Donovan JLL, Galan P, Gilbert R, Giles GGG, Giovannucci E, Goodman GEE, Goodman PJJ, Gunter MJJ, Hamdy FCC, Heliövaara M, Helzlsouer KJJ, Henderson BEE, Hercberg S, Hoffman-Bolton J, Hoover RNN, 
Johansson M, Khaw K-TT, King IBB, Knekt P, Kolonel LNN, Le Marchand L, Männistö S, Martin RMM, Meyer HEE, Mondul AMM, Moy KAA, Neal DEE, Neuhouser MLL, Palli D, Platz EAA, Pouchieu C, Rissanen H, Schenk JMM, Severi G, Stampfer MJJ, Tjønneland A, Touvier M, Trichopoulou A, Weinstein SJJ, Ziegler RGG, Zhou CKK and Allen NEE: Carotenoids, retinol, tocopherols, and prostate cancer risk: Pooled analysis of 15 studies. Am J Clin Nutr 102(5): 1142-1157, 2015. PMID: 26447150. DOI: 10.3945/ajcn.115.114306

88 Stahl W, Schwarz W, Sundquist AR and Sies H: Cis-trans isomers of lycopene and $\beta$-carotene in human serum and tissues. Arch Biochem Biophys 294(1): 173-177, 1992. PMID: 1550343. DOI: 10.1016/0003-9861(92)90153-N

89 Campbell DR, Gross MD, Martini MC, Grandits GA, Slavin JL and Potter JD: Plasma carotenoids as biomarkers of vegetable and fruit intake. Cancer Epidemiol Biomarkers Prev 3(6): 493500, 1994. PMID: 8000300.

90 Yong LC, Forman MR, Beecher GR, Graubard BI, Campbell WS, Reichman ME, Taylor PR, Lanza E, Holden JM and Judd JT: Relationship between dietary intake and plasma concentrations of carotenoids in premenopausal women: application of the USDA-NCI carotenoid food-composition database. Am J Clin Nutr 60(2): 223-230, 1994. PMID: 8030600. DOI: $10.1093 /$ ajcn/60.2.223

91 Willett W: Nutritional Epidemiology. Oxford University Press, 2012. DOI: 10.1093/acprof:oso/9780199754038.001.0001

92 Chen P, Zhang W, Wang X, Zhao K, Negi DS, Zhuo L, Qi M, Wang $X$ and Zhang $X$ : Lycopene and risk of prostate cancer: $A$ systematic review and meta-analysis. Medicine (Baltimore) 94(33): e1260, 2015. PMID: 26287411. DOI: 10.1097/MD. 0000000000001260

93 Wang Y, Cui R, Xiao Y, Fang J and Xu Q: Effect of carotene and lycopene on the risk of prostate cancer: A systematic review and dose-response meta-analysis of observational studies. PLoS One 10(9), 2015. PMID: 26372549. DOI: 10.1371/JOURNAL.PONE. 0137427

94 Rowles JL, Ranard KM, Smith JW, An R and Erdman JW: Increased dietary and circulating lycopene are associated with reduced prostate cancer risk: a systematic review and metaanalysis. Prostate Cancer Prostatic Dis 20(4): 361-377, 2017. PMID: 28440323. DOI: 10.1038/pcan.2017.25

95 Cui K, Li X, Du Y, Tang X, Arai S, Geng Y, Xi Y, Xu H, Zhou $\mathrm{Y}, \mathrm{Ma} \mathrm{W}$ and Zhang T: Chemoprevention of prostate cancer in men with high-grade prostatic intraepithelial neoplasia (HGPIN): a systematic review and adjusted indirect treatment comparison. Oncotarget 8(22): 36674-36684, 2017. PMID: 28415774. DOI: 10.18632/oncotarget.16230

96 Butt MS, Ahmad RS, Sultan MT, Qayyum MMN and Naz A: Green tea and anticancer perspectives: Updates from last decade. Crit Rev Food Sci Nutr 55(6): 792-805, 2015. PMID: 24915354. DOI: $10.1080 / 10408398.2012 .680205$

97 Weisburger JH and Chung FL: Mechanisms of chronic disease causation by nutritional factors and tobacco products and their prevention by tea polyphenols. Food Chem Toxicol 40(8): 11451154, 2002. PMID: 12067577.

98 Bettuzzi S, Brausi M, Rizzi F, Castagnetti G, Peracchia G and Corti A: Chemoprevention of human prostate cancer by oral administration of green tea catechins in volunteers with highgrade prostate intraepithelial neoplasia: A preliminary report from a one-year proof-of-principle study. Cancer Res 66(2): 1234-
1240, 2006. PMID: 16424063. DOI: 10.1158/0008-5472.CAN05-1145

99 Wang P, Aronson WJ, Huang M, Zhang Y, Lee R-P, Heber D and Henning SM: Green tea polyphenols and metabolites in prostatectomy tissue: implications for cancer prevention. Cancer Prev Res (Phila) 3(8): 985-993, 2010. PMID: 20628004. DOI: 10.1158/1940-6207.CAPR-09-0210

100 Henning SM, Wang P, Said JW, Huang M, Grogan T, Elashoff D, Carpenter CL, Heber D and Aronson WJ: Randomized clinical trial of brewed green and black tea in men with prostate cancer prior to prostatectomy. Prostate 75(5): 550-559, 2015. PMID: 25545744. DOI: 10.1002/pros.22943

101 Zheng J, Yang B, Huang T, Yu Y, Yang J and Li D: Green tea and black tea consumption and prostate cancer risk: An exploratory meta-analysis of observational studies. Nutr Cancer 63(5): 663672, 2011. PMID: 21667398. DOI: 10.1080/01635581. 2011.570895

102 Lin Y, Hu Z, Wang X, Mao Q, Qin J, Zheng X and Xie L: Tea consumption and prostate cancer: an updated meta-analysis. World J Surg Oncol 12: 38, 2014. PMID: 24528523. DOI: 10.1186/1477-7819-12-38

103 Fei X, Shen Y, Li X and Guo H: The association of tea consumption and the risk and progression of prostate cancer: a meta-analysis. Int J Clin Exp Med 7(11): 3881-3891, 2014. PMID: 25550896.

104 Jacob SA, Khan TM and Lee LH: The effect of green tea consumption on prostate cancer risk and progression: A systematic review. Nutr Cancer 69(3): 353-364, 2017. PMID: 28287319. DOI: 10.1080/01635581.2017.1285037

105 Guo Y, Zhi F, Chen P, Zhao K, Xiang H, Mao Q, Wang X and Zhang X: Green tea and the risk of prostate cancer: A systematic review and meta-analysis. Medicine (Baltimore) 96(13): e6426, 2017. PMID: 28353571. DOI: 10.1097/MD.0000000000006426

106 Paltsev M, Kiselev V, Drukh V, Muyzhnek E, Kuznetsov I, Andrianova E and Baranovskiy P: First results of the doubleblind randomized placebo-controlled multicenter clinical trial of DIM-based therapy designed as personalized approach to reverse prostatic intraepithelial neoplasia (PIN). EPMA J 7(1): 5, 2016. PMID: 27042242. DOI: 10.1186/s13167-016-0057-3

107 Hoang VD, Lee AH, Pham NM, Xu D and Binns CW: Habitual tea consumption reduces prostate cancer risk in Vietnamese Men: A case-control study. Asian Pac J Cancer Prev 17(11): 49394944, 2016. PMID: 28032720. DOI: 10.22034/APJCP.2016. 17.11.4939

108 Kumar NB, Pow-Sang J, Egan KM, Spiess PE, Dickinson S, Salup R, Helal M, McLarty J, Williams CR, Schreiber F, Parnes HL, Sebti S, Kazi A, Kang L, Quinn G, Smith T, Yue B, Diaz K, Chornokur G, Crocker T and Schell MJ: Randomized, placebocontrolled trial of green tea catechins for prostate cancer prevention. Cancer Prev Res 8(10): 879-887, 2015. PMID: 25873370. DOI: 10.1158/1940-6207.CAPR-14-0324

109 Brausi M, Rizzi F and Bettuzzi S: Chemoprevention of human prostate cancer by green tea catechins: Two years later. A followup update. Eur Urol 54(2): 472-473, 2008. PMID: 18406041. DOI: $10.1016 /$ j.eururo.2008.03.100

110 Gupta S, Hussain T and Mukhtar H: Molecular pathway for (-)epigallocatechin-3-gallate-induced cell cycle arrest and apoptosis of human prostate carcinoma cells. Arch Biochem Biophys 410(1): 177-185, 2003. PMID: 12559991. DOI: 10.1016/S00039861(02)00668-9 
111 Kao Y-HH, Hiipakka RAA and Liao S: Modulation of endocrine systems and food intake by green tea epigallocatechin gallate. Endocrinology 141(3): 980-987, 2000. PMID: 10698173. DOI: 10.1210/endo.141.3.7368

112 Liao SS and Hiipakka RA: Selective-inhibition of steroid $5 \alpha$ reductase isozymes by tea epicatechin-3-gallate and epigallocatechin-3-gallate. Biochem Biophys Res Commun 214(3): 833-838, 1995. PMID: 7575552. DOI: 10.1006/BBRC.1995.2362

113 McLarty J, Bigelow RLH, Smith M, Elmajian D, Ankem M and Cardelli JA: Tea polyphenols decrease serum levels of prostate-specific antigen, hepatocyte growth factor, and vascular endothelial growth factor in prostate cancer patients and inhibit production of hepatocyte growth factor and vascular endothelial growth factor in vitro. Cancer Prev Res 2(7): 673-682, 2009. PMID: 19542190. DOI: 10.1158/19406207.CAPR-08-0167

114 Yang P, He X and Malhotra A: Epigenetic targets of polyphenols in cancer. J Environ Pathol Toxicol Oncol 33(2): 159-165, 2014. PMID: 24941298. DOI: 10.1615/JEnvironPatholToxicol Oncol.2014011094

115 Beltz LA, Bayer DK, Moss AL and Simet IM: Mechanisms of cancer prevention by green and black tea polyphenols. Anticancer Agents Med Chem 6(5): 389-406, 2006. PMID: 17017850.

116 Sur S and Panda CK: Molecular aspects of cancer chemopreventive and therapeutic efficacies of tea and tea polyphenols. Nutrition 43-44: 8-15, 2017. PMID: 28935149. DOI: 10.1016/j.nut.2017.06.006

117 Chikara S, Nagaprashantha LD, Singhal J, Horne D, Awasthi S and Singhal SS: Oxidative stress and dietary phytochemicals: Role in cancer chemoprevention and treatment. Cancer Lett 413: 122-134, 2018. PMID: 29113871. DOI: 10.1016/j.canlet.2017.11.002

118 Min NY, Kim J-H, Choi J-H, Liang W, Ko YJ, Rhee S, Bang H, Ham SW, Park AJ and Lee K-H: Selective death of cancer cells by preferential induction of reactive oxygen species in response to (-)-epigallocatechin-3-gallate. Biochem Biophys Res Commun 421(1): 91-97, 2012. PMID: 22487794. DOI: 10.1016/j.bbrc. 2012.03.120

119 Farhan M, Khan HY, Oves M, Al-Harrasi A, Rehmani N, Arif H, Hadi SM and Ahmad A: Cancer therapy by catechins involves redox cycling of copper ions and generation of reactive oxygen species. Toxins (Basel) 8(2): 37, 2016. PMID: 26861392. DOI: 10.3390/toxins 8020037

120 Khan MA, Gahlot S and Majumdar S: Oxidative stress induced by curcumin promotes the death of cutaneous $\mathrm{t}$-cell lymphoma (HuT-78) by disrupting the function of several molecular targets. Mol Cancer Ther 11(9): 1873-1883, 2012. PMID: 22653966. DOI: 10.1158/1535-7163.MCT-12-0141

121 Yoshino M, Haneda M, Naruse M, Htay HH, Tsubouchi R, Qiao S Lou, Li WH, Murakami K and Yokochi T: Prooxidant activity of curcumin: copper-dependent formation of 8-hydroxy-2'deoxyguanosine in DNA and induction of apoptotic cell death Toxicol Vitr 18(6): 783-789, 2004. PMID: 15465643. DOI: 10.1016/J.TIV.2004.03.009

122 Athar M, Back JH, Kopelovich L, Bickers DR and Kim AL: Multiple molecular Targets of Resveratrol: Anti-carcinogenic mechanisms. Arch Biochem Biophys 486(2): 95, 2009. PMID: 19514131. DOI: 10.1016/J.ABB.2009.01.018

123 Bradlow HL: Review. Indole-3-carbinol as a chemoprotective agent in breast and prostate cancer. In Vivo 22(4): 441-445. PMID: 18712169
124 Katz E, Nisani S and Chamovitz DA: Indole-3-carbinol: a plant hormone combatting cancer. F1000Research 7: 689, 2018. PMID: 29904587. DOI: 10.12688/f1000research.14127.1

125 Verhoeven DTH, Verhagen H, Goldbohm RA, Van Den Brandt PA and Van Poppel G: A review of mechanisms underlying anticarcinogenicity by brassica vegetables. Chem Biol Interact 103(2): 79-129, 1997. PMID: 9055870. DOI: 10.1016/S00092797(96)03745-3

126 Aggarwal BB and Ichikawa H: Molecular targets and anticancer potential of indole-3-carbinol and its derivatives. Cell Cycle 4(9): 1201-1215, 2005. PMID: 16082211. DOI: 10.4161/cc.4.9.1993

127 Fujioka N, Fritz V, Upadhyaya P, Kassie F and Hecht SS: Research on cruciferous vegetables, indole-3-carbinol, and cancer prevention: A tribute to Lee W. Wattenberg. Mol Nutr Food Res 60(6): 1228-1238, 2016. PMID: 26840393. DOI: 10.1002/mnfr. 201500889

128 Atwell LL, Beaver LM, Shannon J, Williams DE, Dashwood RH and Ho E: Epigenetic regulation by sulforaphane: Opportunities for breast and prostate cancer chemoprevention. Curr Pharmacol Reports 1(2): 102-111, 2015. PMID: 26042194. DOI: 10.1007/ s40495-014-0002-x

129 Xiao D, Srivastava SK, Lew KL, Zeng Y, Hershberger P, Johnson CS, Trump DL and Singh SV: Allyl isothiocyanate, a constituent of cruciferous vegetables, inhibits proliferation of human prostate cancer cells by causing $\mathrm{G}_{2} / \mathrm{M}$ arrest and inducing apoptosis. Carcinogenesis 24(5): 891-897, 2003. PMID: 12771033. DOI: $10.1093 / \mathrm{carcin} / \mathrm{bgg} 023$

130 Xu C, Shen G, Chen C, Gélinas C and Kong A-NT: Suppression of NF-kB and NF-kB-regulated gene expression by sulforaphane and PEITC through IкB $\alpha$, IKK pathway in human prostate cancer PC-3 cells. Oncogene 24(28): 4486-4495, 2005. PMID: 15856023. DOI: $10.1038 /$ sj.onc. 1208656

131 Saw CL-L, Cintrón M, Wu TY, Guo Y, Huang Y, Jeong WS and Kong A-NT: Pharmacodynamics of dietary phytochemical indoles I3C and DIM: Induction of Nrf2-mediated phase II drug metabolizing and antioxidant genes and synergism with isothiocyanates. Biopharm Drug Dispos 32(5): 289-300, 2011. PMID: 21656528. DOI: 10.1002/bdd.759

$132 \mathrm{Xu} \mathrm{C}$ : Mechanism of action of isothiocyanates: the induction of ARE-regulated genes is associated with activation of ERK and JNK and the phosphorylation and nuclear translocation of Nrf2. Mol Cancer Ther 5(8): 1918-1926, 2006. PMID: 16928811. DOI: 10.1158/1535-7163.MCT-05-0497

133 Hu R, Hebbar V, Kim B-R, Chen C, Winnik B, Buckley B, Soteropoulos P, Tolias P, Hart RP and Kong A-NT: In vivo pharmacokinetics and regulation of gene expression profiles by isothiocyanate sulforaphane in the rat. J Pharmacol Exp Ther 310(1): 263-271, 2004. PMID: 14988420. DOI: 10.1124/jpet.103. 064261

134 Brooks JD, Paton VG and Vidanes G: Potent induction of phase 2 enzymes in human prostate cells by sulforaphane. Cancer Epidemiol Biomarkers Prev 10(9): 949-954, 2001. PMID: 11535546.

135 Myzak MC, Dashwood WM, Orner GA, Ho E and Dashwood RH: Sulforaphane inhibits histone deacetylase in vivo and suppresses tumorigenesis in Apc-minus mice. FASEB J 20(3): 506-508, 2006. PMID: 16407454. DOI: 10.1096/fj.05-4785fje

136 Myzak MC, Hardin K, Wang R, Dashwood RH and Ho E: Sulforaphane inhibits histone deacetylase activity in BPH-1, 
LnCaP and PC-3 prostate epithelial cells. Carcinogenesis 27(4): 811-819, 2006. PMID: 16280330. DOI: 10.1093/carcin/bgi265

137 Reddy L, Odhav B and Bhoola KD: Natural products for cancer prevention: A global perspective. Pharmacol Ther 99(1): 1-13, 2003. PMID: 12804695. DOI: 10.1016/S0163-7258(03)00042-1

138 Powolny AA, Bommareddy A, Hahm ER, Normolle DP, Beumer JH, Nelson JB and Singh SV: Chemopreventative potential of the cruciferous vegetable constituent phenethyl isothiocyanate in a mouse model of prostate cancer. J Natl Cancer Inst 103(7): 571584, 2011. PMID: 21330634. DOI: 10.1093/jnci/djr029

139 Cipolla BG, Mandron E, Lefort JM, Coadou Y, Della Negra E, Corbel L, Le Scodan R, Azzouzi AR and Mottet N: Effect of sulforaphane in men with biochemical recurrence after radical prostatectomy. Cancer Prev Res 8(8): 712-719, 2015. PMID: 25968598. DOI: 10.1158/1940-6207.CAPR-14-0459

140 Bindukumar B, Schwartz SA, Nair MPN, Aalinkeel R, Kawinski $\mathrm{E}$ and Chadha KC: Prostate-specific antigen modulates the expression of genes involved in prostate tumor growth. Neoplasia 7(3): 241-252, 2005. PMID: 15799824. DOI: 10.1593/neo.04529

141 Gilbert SM, Cavallo CB, Kahane H and Lowe FC: Evidence suggesting PSA cutpoint of $2.5 \mathrm{ng} / \mathrm{mL}$ for prompting prostate biopsy: Review of 36,316 biopsies. Urology 65(3): 549-553, 2005. PMID: 15780374. DOI: 10.1016/j.urology.2004.10.064

142 Scher HI, Halabi S, Tannock I, Morris M, Sternberg CN, Carducci MA, Eisenberger MA, Higano C, Bubley GJ, Dreicer R, Petrylak D, Kantoff P, Basch E, Kelly WK, Figg WD, Small EJ, Beer TM, Wilding G, Martin A, Hussain M and Prostate Cancer Clinical Trials Working Group: Design and end points of clinical trials for patients with progressive prostate cancer and castrate levels of testosterone: recommendations of the Prostate Cancer Clinical Trials Working Group. J Clin Oncol 26(7): 11481159, 2008. PMID: 18309951. DOI: 10.1200/JCO.2007.12.4487

143 Taneja SS, Morton R, Barnette G, Sieber P, Hancock ML and Steiner M: Prostate cancer diagnosis among men with isolated high-grade intraepithelial neoplasia enrolled onto a 3-year prospective phase III clinical trial of oral toremifene. J Clin Oncol 31(5): 523-529, 2013. PMID: 23295793. DOI: 10.1200/ JCO.2012.41.7634

144 Gee J, Bailey H, Kim K, Kolesar J, Havighurst T, Tutsch KD, See W, Cohen MB, Street N, LeVan L, Jarrard D and Wilding G: Phase II open label, multi-center clinical trial of modulation of intermediate endpoint biomarkers by $1 \alpha$-hydroxyvitamin D2 in patients with clinically localized prostate cancer and high grade pin. Prostate 73(9): 970-978, 2013. PMID: 23335089. DOI: $10.1002 /$ pros. 22644

145 D’Amico AV, Whittington R, Malkowicz SB, Schultz D, Blank K, Broderick GA, Tomaszewski JE, Renshaw AA, Kaplan I, Beard CJ and Wein A: Biochemical outcome after radical prostatectomy, external beam radiation therapy, or interstitial radiation therapy for clinically localized prostate cancer. JAMA 280(11): 969, 1998. PMID: 9749478. DOI: 10.1001/jama.280.11.969

146 Amin MM, Jeyaganth S, Fahmy N, Bégin L, Aronson S, Jacobson S, Tanguay S and Aprikian AG: Subsequent prostate cancer detection in patients with prostatic intraepithelial neoplasia or atypical small acinar proliferation. Can Urol Assoc J 1(3): 245-249, 2007. PMID: 18542796. DOI: 10.5489/cuaj.77

147 Lilja H, Ulmert D and Vickers AJ: Prostate-specific antigen and prostate cancer: prediction, detection and monitoring. Nat Rev Cancer 8(4): 268-278, 2008. PMID: 18337732. DOI: 10.1038/ $\operatorname{nrc} 2351$
148 Bryant RJ and Lilja H: Emerging PSA-based tests to improve screening. Urol Clin North Am 41(2): 267-276, 2014. PMID: 24725489. DOI: 10.1016/j.ucl.2014.01.003

149 Liu B, Mao Q, Cao M and Xie L: Cruciferous vegetables intake and risk of prostate cancer: A meta-analysis. Int J Urol 19(2): 134-141, 2012. PMID: 22121852. DOI: 10.1111/j.14422042.2011.02906.x

150 Bosetti C, Filomeno M, Riso P, Polesel J, Levi F, Talamini R, Montella M, Negri E, Franceschi $S$ and La Vecchia C: Cruciferous vegetables and cancer risk in a network of casecontrol studies. Ann Oncol 23(8): 2198-2203, 2012. PMID: 22328735. DOI: $10.1093 /$ annonc/mdr604

151 Richman EL, Carroll PR and Chan JM: Vegetable and fruit intake after diagnosis and risk of prostate cancer progression. Int $\mathbf{J}$ cancer 131(1): 201-210, 2012. PMID: 21823116. DOI: 10.1002/ ijc. 26348

152 Kasiotis KMM, Pratsinis H, Kletsas D and Haroutounian SAA: Resveratrol and related stilbenes: Their anti-aging and antiangiogenic properties. Food Chem Toxicol 61: 112-120, 2013. PMID: 23567244. DOI: 10.1016/j.fct.2013.03.038

153 Jang M, Cai L, Udeani GO, Slowing K V, Thomas CF, Beecher CW, Fong HH, Farnsworth NR, Kinghorn AD, Mehta RG, Moon RC and Pezzuto JM: Cancer chemopreventive activity of resveratrol, a natural product derived from grapes. Science 275(5297): 218-220, 1997. PMID: 8985016. DOI: 10.1126/ SCIENCE.275.5297.218

154 Carter LG, D’Orazio JA and Pearson KJ: Resveratrol and cancer: focus on in vivo evidence. Endocr Relat Cancer 21(3): R209-225, 2014. PMID: 24500760. DOI: 10.1530/ERC-13-0171

155 Kowalczyk MC, Kowalczyk P, Tolstykh O, Hanausek M, Walaszek Z and Slaga TJ: Synergistic effects of combined phytochemicals and skin cancer prevention in SENCAR Mice. Cancer Prev Res 3(2): 170-178, 2010. PMID: 20103723. DOI: 10.1158/1940-6207.CAPR-09-0196

156 Chen CY, Jang JH, Li MH and Surh YJ: Resveratrol upregulates heme oxygenase-1 expression via activation of NF-E2-related factor 2 in PC12 cells. Biochem Biophys Res Commun 331(4): 993-1000, 2005. PMID: 15882976. DOI: 10.1016/J.BBRC. 2005.03.237

157 Xue D, Zhou C, Shi Y, Lu H, Xu R and He X: Nuclear transcription factor Nrf2 suppresses prostate cancer cells growth and migration through upregulating ferroportin. Oncotarget 7(48): 78804-78812, 2016. PMID: 27788496. DOI: 10.18632/ oncotarget. 12860

158 Khurana N and Sikka SC: Targeting Crosstalk between Nrf-2, $\mathrm{NF}-\mathrm{kB}$ and androgen receptor signaling in prostate cancer. Cancers (Basel) 10(10), 2018. PMID: 30257470. DOI: 10.3390/cancers 10100352

159 Limagne E, Lançon A, Delmas D, Cherkaoui-Malki M and Latruffe N: Resveratrol interferes with IL1- $\beta$-induced proinflammatory paracrine interaction between primary chondrocytes and macrophages. Nutrients 8(5), 2016. PMID: 27187448. DOI: $10.3390 / \mathrm{NU} 8050280$

160 Bakhle YS: COX-2 and cancer: a new approach to an old problem. Br J Pharmacol 134(6): 1137-1150, 2001. PMID: 11704632. DOI: 10.1038/sj.bjp.0704365

161 Nelson WG, De Marzo AM, Deweese TL and Isaacs WB: The role of inflammation in the pathogenesis of prostate cancer. $\mathrm{J}$ Urol 172(5S), 2004. PMID: 15535435. DOI: 10.1097/ 01.ju.0000142058.99614.ff 
162 Nonn L, Duong D and Peehl DM: Chemopreventive antiinflammatory activities of curcumin and other phytochemicals mediated by MAP kinase phosphatase- 5 in prostate cells Carcinogenesis 28(6): 1188-1196, 2007. PMID: 17151092. DOI: 10.1093/carcin/bgl241

163 Chung JH, Manganiello V and Dyck JRB: Resveratrol as a calorie restriction mimetic: therapeutic implications. Trends Cell Biol 22(10): 546-554, 2012. PMID: 22885100. DOI: 10.1016/ j.tcb.2012.07.004

164 Szewczuk LM, Forti L, Stivala LA and Penning TM: Resveratrol is a Peroxidase-mediated Inactivator of COX-1 but Not COX-2. J Biol Chem 279(21): 22727-22737, 2004. DOI: 10.1074/ jbc.M314302200

165 Das S and Das DK: Anti-inflammatory responses of resveratrol. Inflamm Allergy Drug Targets 6(3): 168-173, 2007. PMID: 17897053. DOI: $10.1007 / \mathrm{s} 10552-010-9527-4$

166 Blagosklonny MV: An anti-aging drug today: from senescencepromoting genes to anti-aging pill. Drug Discov Today 12(5-6): 218-224, 2007. PMID: 17331886. DOI: 10.1016/j.drudis. 2007.01 .004

167 Kundu JK, Chun KS, Kim SO and Surh YJ: Resveratrol inhibits phorbol ester-induced cyclooxygenase-2 expression in mouse skin: MAPKs and AP-1 as potential molecular targets. Biofactors 21(1-4): 33-39, 2004. PMID: 15630167.

168 Kundu JK, Shin YK, Kim SH and Surh YJ: Resveratrol inhibits phorbol ester-induced expression of COX-2 and activation of NF-kB in mouse skin by blocking IKB kinase activity. Carcinogenesis 27(7): 1465-1474, 2006. PMID: 16474181. DOI: 10.1093/carcin/bgi349

169 Yuan H, Pan Y and Young CYFYF: Overexpression of c-Jun induced by quercetin and resverol inhibits the expression and function of the androgen receptor in human prostate cancer cells. Cancer Lett 213(2): 155-163, 2004. PMID: 15327830. DOI: 10.1016/j.canlet.2004.04.003

170 Dhar S, Kumar A, Li K, Tzivion G and Levenson AS: Resveratrol regulates PTEN/Akt pathway through inhibition of MTA1/HDAC unit of the NuRD complex in prostate cancer. Biochim Biophys Acta - Mol Cell Res 1853(2): 265-275, 2015. DOI: 10.1016/J.BBAMCR.2014.11.004

171 Kumar A, Dhar S, Rimando AM, Lage JM, Lewin JR, Zhang $\mathrm{X}$ and Levenson AS: Epigenetic potential of resveratrol and analogs in preclinical models of prostate cancer. Ann NY Acad Sci 1348(1): 1-9, 2015. PMID: 26214308. DOI: 10.1111/ nyas. 12817

172 Benitez DA, Pozo-Guisado E, Alvarez-Barrientos A, FernandezSalguero PM and Castellon EA: Mechanisms involved in resveratrol-induced apoptosis and cell cycle arrest in prostate cancer-derived cell lines. J Androl 28(2): 282-293, 2006. PMID: 17050787. DOI: 10.2164 /jandrol.106.000968

173 Chakraborty S, Kumar A, Butt NA, Zhang L, Williams R, Rimando AM, Biswas PK and Levenson AS: Molecular insight into the differential anti-androgenic activity of resveratrol and its natural analogs: in silico approach to understand biological actions. Mol Biosyst 12(5): 1702-1709, 2016. PMID: 27063447. DOI: $10.1039 / \mathrm{c} 6 \mathrm{mb} 00186 \mathrm{f}$

174 Benitez DA, Pozo-Guisado E, Clementi M, Castellón E and Fernandez-Salguero PM: Non-genomic action of resveratrol on androgen and oestrogen receptors in prostate cancer: modulation of the phosphoinositide 3-kinase pathway. Br J Cancer 96(10): 1595, 2007. PMID: 17486135. DOI: 10.1038/SJ.BJC.6603755
175 Mitani T, Harada N, Tanimori S, Nakano Y, Inui H And Yamaji R: Resveratrol inhibits hypoxia-inducible factor-1 alpha;mediated androgen receptor signaling and represses tumor progression in castration-resistant prostate cancer. J Nutr Sci Vitaminol (Tokyo) 60(4): 276-282, 2014. PMID: 25297617. DOI: $10.3177 /$ jnsv.60.276

176 Gacci M, Russo GI, De Nunzio C, Sebastianelli A, Salvi M, Vignozzi L, Tubaro A, Morgia G and Serni S: Meta-analysis of metabolic syndrome and prostate cancer. Prostate Cancer Prostatic Dis 20(2): 146-155, 2017. PMID: 28220805. DOI: 10.1038/pcan.2017.1

177 Kjaer TN, Ornstrup MJ, Poulsen MM, Jørgensen JOL, Hougaard DM, Cohen AS, Neghabat S, Richelsen B and Pedersen SB: Resveratrol reduces the levels of circulating androgen precursors but has no effect on, testosterone, dihydrotestosterone, PSA levels or prostate volume. A 4-month randomised trial in middleaged men. Prostate 75(12): 1255-1263, 2015. PMID: 25939591. DOI: $10.1002 /$ pros.23006

178 Paller CJ, Rudek MA, Zhou XC, Wagner WD, Hudson TS, Anders N, Hammers HJ, Dowling D, King S, Antonarakis ES, Drake CG, Eisenberger MA, Denmeade SR, Rosner GL and Carducci MA: A phase I study of muscadine grape skin extract in men with biochemically recurrent prostate cancer: Safety, tolerability, and dose determination. Prostate 75(14): 1518-1525, 2015. PMID: 26012728. DOI: 10.1002/pros.23024

179 George J, Singh M, Srivastava AK, Bhui K, Roy P, Chaturvedi PK and Shukla Y: Resveratrol and black tea polyphenol combination synergistically suppress mouse skin tumors growth by inhibition of activated MAPKs and p53. PLoS One 6(8): e23395, 2011. PMID: 21887248. DOI: 10.1371/journal.pone.0023395

180 Schlachterman A, Valle F, Wall KM, Azios NG, Castillo L, Morell L, Washington AV, Cubano LA and Dharmawardhane SF: Combined resveratrol, quercetin, and catechin treatment reduces breast tumor growth in a nude mouse model. Transl Oncol 1(1): 19-27, 2008. PMID: 18607509.

181 Malhotra A, Nair P and Dhawan DK: Curcumin and resveratrol synergistically stimulate $\mathrm{p} 21$ and regulate cox-2 by maintaining adequate zinc levels during lung carcinogenesis. Eur J Cancer Prev 20(5): 411-416, 2011. PMID: 21633290. DOI: 10.1097/ CEJ.0b013e3283481d71

182 Sharma N, Dobhal M, Joshi Y and Chahar M: Flavonoids: A versatile source of anticancer drugs. Pharmacogn Rev 5(9): 1, 2011. PMID: 22096313. DOI: 10.4103/0973-7847.79093

183 Gibellini L, Pinti M, Nasi M, Montagna JP, De Biasi S, Roat E, Bertoncelli L, Cooper EL and Cossarizza A: Quercetin and cancer chemoprevention. Evid Based Complement Alternat Med 2011: 591356, 2011. PMID: 21792362. DOI: 10.1093/ecam/neq053

184 Rauf A, Imran M, Khan IA, Ur-Rehman M, Gilani SA, Mehmood Z and Mubarak MS: Anticancer potential of quercetin: A comprehensive review. Phyther Res 32(11): 2109-2130, 2018. PMID: 30039547. DOI: 10.1002/ptr.6155

185 Carlos-Reyes Á, López-González JS, Meneses-Flores M, Gallardo-Rincón D, Ruíz-García E, Marchat LA, Astudillo-de la Vega H, Hernández de la Cruz ON and López-Camarillo C: Dietary compounds as epigenetic modulating agents in cancer. Front Genet 10: 79, 2019. PMID: 30881375. DOI: 10.3389/ fgene.2019.00079

186 Vijayababu MR, Arunkumar A, Kanagaraj P and Arunakaran J: Effects of quercetin on insulin-like growth factors (IGFs) and their binding protein-3 (IGFBP-3) secretion and induction of 
apoptosis in human prostate cancer cells. J Carcinog 5: 10, 2006 PMID: 16600019. DOI: 10.1186/1477-3163-5-10

187 Erdogan S, Turkekul K, Dibirdik I, Doganlar O, Doganlar ZB, Bilir A and Oktem G: Midkine downregulation increases the efficacy of quercetin on prostate cancer stem cell survival and migration through PI3K/AKT and MAPK/ERK pathway. Biomed Pharmacother 107(9): 793-805, 2018. PMID: 30142541. DOI: 10.1016/j.biopha.2018.08.061

188 Askari F, Parizi MK, Jessri M and Rashidkhani B: Fruit and vegetable intake in relation to prostate cancer in Iranian men: a case-control study. Asian Pac J Cancer Prev 15(13): 5223-5227, 2014. PMID: 25040978. DOI: 10.7314/apjcp.2014.15.13.5223

189 Gallus S, Talamini R, Giacosa A, Montella M, Ramazzotti V, Franceschi S, Negri E and La Vecchia C: Does an apple a day keep the oncologist away? 16(11), 2005. PMID: 16091428. DOI: 10.1093/annonc/mdi361

190 Hollman P and Katan M: Absorption, metabolism and health effects of dietary flavonoids in man. Biomed Pharmacother 51(8): 305-310, 1997. PMID: 9436520. DOI: 10.1016/S07533322(97)88045-6

191 Harborne JB and Mabry TJ: The Flavonoids. Harborne JB and Mabry TJ (eds.). Boston, MA, Springer US, 1982. DOI: 10.1007/978-1-4899-2915-0

192 Aggarwal BBB and Harikumar KBB: Potential therapeutic effects of curcumin, the anti-inflammatory agent, against neurodegenerative, cardiovascular, pulmonary, metabolic, autoimmune and neoplastic diseases. Int J Biochem Cell Biol 41(1): 40-59, 2009. PMID: 18662800. DOI: 10.1016/j.biocel.2008.06.010

193 Mimeault M and Batra SK: Potential applications of curcumin and its novel synthetic analogs and nanotechnology-based formulations in cancer prevention and therapy. Chin Med 6: 31, 2011. PMID: 21859497. DOI: 10.1186/1749-8546-6-31

194 Allegra A, Innao V, Russo S, Gerace D, Alonci A and Musolino $\mathrm{C}$ : Anticancer activity of curcumin and its analogues: preclinical and clinical studies. Cancer Invest 35(1): 1-22, 2017. PMID: 27996308. DOI: 10.1080/07357907.2016.1247166

195 Shanmugam MK, Rane G, Kanchi MM, Arfuso F, Chinnathambi A, Zayed ME, Alharbi SA, Tan BKH, Kumar AP and Sethi G: The multifaceted role of curcumin in cancer prevention and treatment. Molecules 20(2): 2728-2769, 2015. PMID: 25665066. DOI: $10.3390 /$ molecules20022728

196 Teiten M-H, Gaascht F, Eifes S, Dicato M and Diederich M: Chemopreventive potential of curcumin in prostate cancer. Genes Nutr 5(1): 61-74, 2010. PMID: 19806380. DOI: 10.1007/s12263009-0152-3

197 Gupta A, Zhou CQ and Chellaiah MA: Osteopontin and MMP9: Associations with VEGF expression/secretion and angiogenesis in PC3 prostate cancer cells. Cancers (Basel) 5(2): 617-638, 2013. PMID: 24216994. DOI: 10.3390/cancers5020617

198 Rana M, Maurya P, Reddy SS, Singh V, Ahmad H, Dwivedi AK, Dikshit M and Barthwal MK: A Standardized chemically modified curcuma longa extract modulates IRAK-MAPK signaling in inflammation and potentiates cytotoxicity. Front Pharmacol 7: 223, 2016. PMID: 27504095. DOI: 10.3389/fphar.2016.00223

199 Das L and Vinayak M: Long term effect of curcumin in restoration of tumour suppressor p53 and phase-II antioxidant enzymes via activation of Nrf2 signalling and modulation of inflammation in prevention of cancer. PLoS One 10(4): e0124000, 2015. PMID: 25860911. DOI: 10.1371/journal.pone. 0124000
200 Dorai T, Gehani N and Katz A: Therapeutic potential of curcumin in human prostate cancer-I. curcumin induces apoptosis in both androgen-dependent and androgen-independent prostate cancer cells. Prostate Cancer Prostatic Dis 3(2): 84-93, 2000. PMID: 12497104. DOI: 10.1038/sj.pcan.4500399

201 Yang J, Ning J, Peng L and He D: Effect of curcumin on Bcl-2 and Bax expression in nude mice prostate cancer. Int J Clin Exp Pathol 8(8): 9272, 2015. PMID: 26464676.

202 Yu XL, Jing T, Zhao H, Li PJ, Xu WH and Shang FF: Curcumin inhibits expression of inhibitor of DNA binding 1 in PC3 cells and xenografts. Asian Pac J Cancer Prev 15(3): 1465-1470, 2014. PMID: 24606484. DOI: 10.7314/apjcp.2014.15.3.1465

203 John A and Tuszynski G: The role of matrix metalloproteinases in tumor angiogenesis and tumor metastasis. Pathol Oncol Res 7(1): 14-23, 2001. PMID: 11349215.

204 Ravindran J, Prasad S and Aggarwal BB: Curcumin and cancer cells: How many ways can curry kill tumor cells selectively? AAPS J 11(3): 495, 2009. PMID: 19590964. DOI: 10.1208/ S12248-009-9128-X

205 Shah S, Prasad S and Knudsen KE: Targeting pioneering factor and hormone receptor cooperative pathways to suppress tumor progression. Cancer Res 72(5): 1248-1259, 2012. PMID: 22258452. DOI: 10.1158/0008-5472.CAN-11-0943

206 Schaffer M, Schaffer PM and Bar-Sela G: An update on Curcuma as a functional food in the control of cancer and inflammation. Curr Opin Clin Nutr Metab Care 18(6): 605-611, 2015. PMID: 26418821. DOI: 10.1097/MCO.0000000000000227

207 Tabrizi R, Vakili S, Akbari M, Mirhosseini N, Lankarani KB, Rahimi M, Mobini M, Jafarnejad S, Vahedpoor Z and Asemi $\mathrm{Z}$ : The effects of curcumin-containing supplements on biomarkers of inflammation and oxidative stress: A systematic review and meta-analysis of randomized controlled trials. Phyther Res 33(2): 253-262, 2019. PMID: 30402990. DOI: 10.1002/ptr.6226

208 Qin S, Huang L, Gong J, Shen S, Huang J, Tang Y, Ren H and $\mathrm{Hu} \mathrm{H}$ : Meta-analysis of randomized controlled trials of 4 weeks or longer suggest that curcumin may afford some protection against oxidative stress. Nutr Res 60: 1-12, 2018. PMID: 30527253. DOI: 10.1016/J.NUTRES.2018.08.003

209 Derosa G, Maffioli P, Simental-Mendía LE, Bo S and Sahebkar A: Effect of curcumin on circulating interleukin- 6 concentrations: A systematic review and meta-analysis of randomized controlled trials. Pharmacol Res 111(2): 394-404, 2016. PMID: 27392742. DOI: $10.1016 /$ j.phrs.2016.07.004

210 Sahebkar A, Cicero AFG, Simental-Mendía LE, Aggarwal BB and Gupta SC: Curcumin downregulates human tumor necrosis factor- $\alpha$ levels: A systematic review and meta-analysis ofrandomized controlled trials. Pharmacol Res 107: 234-242, 2016. PMID: 27025786. DOI: 10.1016/J.PHRS.2016.03.026

211 Aggarwal BB, Gupta SC and Sung B: Curcumin: An orally bioavailable blocker of TNF and other pro-inflammatory biomarkers. Br J Pharmacol 169(8): 1672-1692, 2013. PMID: 23425071. DOI: $10.1111 / \mathrm{bph} .12131$

212 Kryvenko ON, Jankowski M, Chitale DA, Tang D, Rundle A, Trudeau $\mathrm{S}$ and Rybicki BA: Inflammation and preneoplastic lesions in benign prostate as risk factors for prostate cancer. Mod Pathol 25(7): 1023-1032, 2012. PMID: 22460812. DOI: 10.1038/ modpathol.2012.51

213 Schatteman PHF, Hoekx L, Wyndaele JJ, Jeuris W and Van Marck E: Inflammation in prostate biopsies of men without prostatic malignancy or clinical prostatitis. Eur Urol 37(4): 404412, 2000. PMID: 10765070. DOI: 10.1159/000020161 
214 Ide H, Tokiwa S, Sakamaki K, Nishio K, Isotani S, Muto S, Hama T, Masuda H and Horie S: Combined inhibitory effects of soy isoflavones and curcumin on the production of prostatespecific antigen. Prostate 70(10): 1127-1133, 2010. PMID: 20503397. DOI: $10.1002 /$ pros. 21147

215 Hejazi J, Rastmanesh R, Taleban FA, Molana SH, Hejazi E, Ehtejab $\mathrm{G}$ and Hara N: Effect of curcumin supplementation during radiotherapy on oxidative status of patients with prostate cancer: A double blinded, randomized, placebo-controlled study. Nutr Cancer 68(1): 77-85, 2016. PMID: 26771294. DOI: $10.1080 / 01635581.2016 .1115527$

216 Adjuvant curcumin to assess recurrence free survival in patients who have had a radical prostatectomy - Full Text View ClinicalTrials.gov. Available from: https://clinicaltrials.gov/ ct2/show/NCT02064673

217 Anand P, Kunnumakkara AB, Newman RA and Aggarwal BB: Bioavailability of curcumin: problems and promises. Mol Pharm 4(6): 807-818, 2007. PMID: 17999464. DOI: 10.1021/mp700113r

218 Khajuria A, Zutshi U and Bedi KL: Permeability characteristics of piperine on oral absorption - an active alkaloid from peppers and a bioavailability enhancer. Indian J Exp Biol 36(1): 46-50, 1998. PMID: 9536651.

219 Shoba G, Joy D, Joseph T, Majeed M, Rajendran R and Srinivas $P$ : Influence of piperine on the pharmacokinetics of curcumin in animals and human volunteers. Planta Med 64(04): 353-356, 1998. PMID: 9619120. DOI: $10.1055 / \mathrm{s}-2006-957450$

220 Manayi A, Nabavi SM, Setzer WN and Jafari S: Piperine as a potential anti-cancer agent: a review on preclinical studies. Curr Med Chem 25(37): 4918-4928, 2019. PMID: 28545378. DOI: $10.2174 / 0929867324666170523120656$

221 Samykutty A, Shetty AV, Dakshinamoorthy G, Bartik MM, Johnson GL, Webb B, Zheng G, Chen A, Kalyanasundaram R and Munirathinam G: Piperine, a bioactive component of pepper spice exerts therapeutic effects on androgen dependent and androgen independent prostate cancer cells. PLoS One 8(6): e65889, 2013. PMID: 23824300. DOI: 10.1371/journal.pone.0065889

222 Ouyang D, Zeng L, Pan H, Xu L, Wang Y, Liu K and He X: Piperine inhibits the proliferation of human prostate cancer cells via induction of cell cycle arrest and autophagy. Food Chem Toxicol 60: 424-430, 2013. PMID: 23939040. DOI: 10.1016/ J.FCT.2013.08.007

223 Makhov P, Golovine K, Canter D, Kutikov A, Simhan J, Corlew MM, Uzzo RG and Kolenko VM: Co-administration of piperine and docetaxel results in improved anti-tumor efficacy via inhibition of CYP3A4 activity. Prostate 72(6): 661-667, 2012. PMID: 21796656. DOI: 10.1002/pros.21469

224 Gumulec J, Masarik M, Krizkova S, Adam V, Hubalek J, Hrabeta $\mathrm{J}$, Eckschlager $\mathrm{T}$, Stiborova $\mathrm{M}$ and Kizek R: Insight to physiology and pathology of zinc(II) ions and their actions in breast and prostate carcinoma. Curr Med Chem 18(33): 50415051, 2011. PMID: 22050752.

225 Hogstrand C, Kille P, Nicholson RI and Taylor KM: Zinc transporters and cancer: a potential role for ZIP7 as a hub for tyrosine kinase activation. Trends Mol Med 15(3): 101-111, 2009. PMID: 19246244. DOI: 10.1016/j.molmed.2009.01.004

226 Zaichick VY, Sviridova TV and Zaichick SV: Zinc in the human prostate gland: Normal, hyperplastic and cancerous. Int Urol Nephrol 29(5): 565-574, 1997. PMID: 9413764. DOI: 10.1007/ BF02552202

227 Singh CK, Pitschmann A and Ahmad N: Resveratrol-zinc combination for prostate cancer management. Cell Cycle 13(12): 1867-1874, 2014. PMID: 24866157. DOI: 10.4161/cc.29334
228 Feng P, Liang JY, Li TL, Guan ZX, Zou J, Franklin R and Costello LC: Zinc induces mitochondria apoptogenesis in prostate cells. Mol Urol 4(1): 31-36, 2000. PMID: 10851304.

229 Chyan W, Zhang DY, Lippard SJ and Radford RJ: Reactionbased fluorescent sensor for investigating mobile $\mathrm{Zn} 2+$ in mitochondria of healthy versus cancerous prostate cells. Proc Natl Acad Sci 111(1): 143-148, 2014. PMID: 24335702. DOI: 10.1073/pnas.1310583110

230 Makhov P, Kutikov A, Golovine K, Uzzo RG, Canter DJ and Kolenko VM: Docetaxel-mediated apoptosis in myeloid progenitor TF-1 cells is mitigated by zinc: Potential implication for prostate cancer therapy. Prostate 71(13): 1413-1419, 2011. PMID: 21308721. DOI: 10.1002/pros.21357

231 Mohler JL: A role for the androgen-receptor in clinically localized and advanced prostate cancer. Best Pract Res Clin Endocrinol Metab 22(2): 357-372, 2008. PMID: 18471792. DOI: 10.1016/j.beem.2008.01.009

232 Plum LM, Rink L and Haase H: The Essential Toxin: Impact of zinc on human health. Int J Environ Res Public Health 7(4): 13421365, 2010. PMID: 20617034. DOI: 10.3390/ijerph7041342

233 Cui D, Han G, Shang Y, Mu L, Long Q and Du Y: The effect of chronic prostatitis on zinc concentration of prostatic fluid and seminal plasma: a systematic review and meta-analysis. Curr Med Res Opin 31(9): 1763-1769, 2015. PMID: 26173049. DOI: 10.1185/03007995.2015.1072707

234 Zhao J, Wu Q, Hu X, Dong X, Wang L, Liu Q, Long Z and Li $\mathrm{L}$ : Comparative study of serum zinc concentrations in benign and malignant prostate disease: A Systematic Review and MetaAnalysis. Sci Rep 6(1): 25778, 2016. PMID: 27170414. DOI: $10.1038 /$ srep 25778

235 Gumulec J, Masarik M, Adam V, Eckschlager T, Provaznik I and Kizek R: Serum and tissue zinc in epithelial malignancies: A Meta-Analysis. PLoS One 9(6): e99790, 2014. PMID: 24941118. DOI: 10.1371/journal.pone.0099790

236 Gonzalez A, Peters U, Lampe JW and White E: Zinc intake from supplements and diet and prostate cancer. Nutr Cancer 61(2): 206215, 2009. PMID: 19235036. DOI: 10.1080/01635580802419749

237 Parsons JK, Pierce JP, Mohler J, Paskett E, Jung S-H, Humphrey P, Taylor JR, Newman VA, Barbier L, Rock CL and Marshall J: A randomized trial of diet in men with early stage prostate cancer on active surveillance: Rationale and design of the Men's Eating and Living (MEAL) Study (CALGB 70807 [Alliance]). Contemp Clin Trials 38(2): 198-203, 2014. PMID: 24837543. DOI: 10.1016/J.CCT.2014.05.002

238 Parsons JK, Pierce JP, Mohler J, Paskett E, Jung S-H, Morris MJ, Small E, Hahn O, Humphrey P, Taylor J and Marshall J: Men's Eating and Living (MEAL) study (CALGB 70807 [Alliance]): recruitment feasibility and baseline demographics of a randomized trial of diet in men on active surveillance for prostate cancer. BJU Int 121(4): 534-539, 2018. PMID: 28437029. DOI: $10.1111 /$ bju. 13890

239 Bray F, Jemal A, Grey N, Ferlay J and Forman D: Global cancer transitions according to the Human Development Index (20082030): a population-based study. Lancet Oncol 13(8): 790-801, 2012. PMID: 22658655. DOI: 10.1016/S1470-2045(12)70211-5

Received August 15, 2019

Revised September 1, 2019 Accepted September 10, 2019 